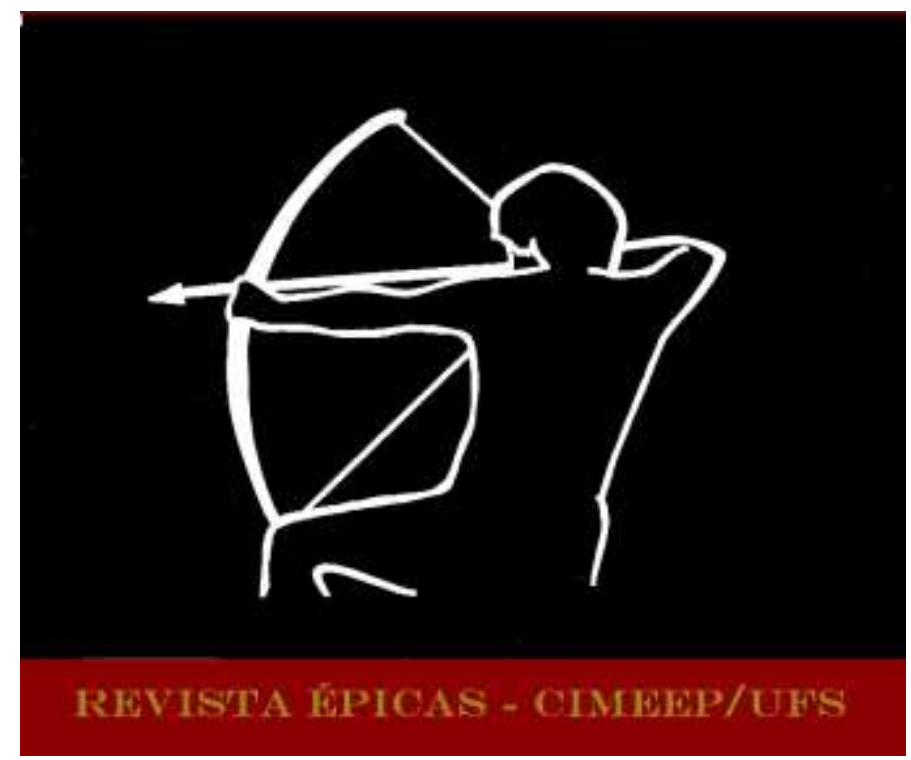

JACQUEMOUD, Clément. Èšua, Učar-kaj, Ak-Byrkan e outros. O renascimento épico na República de Altai (sul da Sibéria). Trad. Antonio Marcos Trindade e Christina Ramalho. In: Revista Épicas. Ano 4, N. 7, Jun 2020, p. 1-35. ISSN 2527-080-X.

\title{
ĖŠUA, UČAR-KAJ, AK-BYRKAN E OUTROS. O RENASCIMENTO ÉPICO NA REPÚBLICA DE ALTAI (SUL DA SIBÉRIA) ${ }^{1}$
}

\author{
ESHUA, UCHAR-KAY, AK-BYRKAN AND OTHERS. \\ EPIC REVIVAL IN ALTAY REPUBLIC (SOUTH SIBERIA)
}

\author{
Clément Jacquemoud ${ }^{2}$ \\ Centre d'Études en Sciences Sociales du Religieux (CéSor)
}

Este artigo é dedicado à memória do kajčy Sarimaj Určimaev (1964-2016)

\footnotetext{
${ }^{1}$ Artigo publicado na Le Recueil Ouvert, com título original: “Ěšua, Učar-kaj, Ak-Byrkan et les autres. Le renouveau épique en République de l'Altaï (Sibérie méridionale)". Referência original completa: JACQUEMOUD, Clément, Ěšua, Učar-kaj, Ak-Byrkan et les autres. Le renouveau épique en République de l'Altaï (Sibérie méridionale). In: Le Recueil Ouvert [En ligne], mis à jour :11/10/2017, URL : http://ouvroir-litt-arts.univ-grenoble-alpes.fr/revues/projet-epopee/269-esua-ucar-kaj-ak-byrkan-et-lesautres-le-renouveau-epique-en-republique-de-l-altai-siberie-meridionale.

2 Dados sobre o autor que constam na publicação original: Clément Jacquemoud é doutorando em Antropologia na Escola Prática de Estudos Avançados de Paris (Laboratório GSRL). Desde 2005, ele trabalha na República de Altai em parceria com os nativos da região. Sua pesquisa, baseada, em parte, em mais de três anos passados no campo, concentra-se na renovação da prática de recitar épicos no canto de garganta. Ele também realiza uma análise comparativa dos rituais dentro dos vários movimentos religiosos presentes na região, concentrando-se no impacto do turismo e da política federal russa no relacionamento dos altaianos com seu território. Publicações: Kögudej-Mergen, héros de Maadaj-Kara, et le chamane. In : Gornyj-Altaj: problemy bilingvizma v polikul'turnom prostranstve. Materialy Meždunarodnoj naučno-praktičeskoj konferencii. g.Gorno-Altajsk 28-30 ljunja 2011 goda, Gorno-Altaisk State University Press, 233-236, 2011 ; Altaj-Buučaj, héros épique de l'entre-deux siècles. In: Études mongoles et sibériennes, centrasiatiques et tibétaines, 45, en ligne: http://emscat.revues.org/2292 ;Les Altaïens, peuple des montagnes de Sibérie . Ed. Fondation Culturelle - Musée BarbierMueller \& Somogy Genève - Paris (também na versão em inglês), 2011 ; L'Altaï, une utopie en construction, Mouvements religieux et sentiments autochtones. In : SAVELLI, D. \& SAMSON, Normand de Chambourg D. (Ed..), a publicar. N. T. Atualmente o professor Jacquemoud é Doutor Associado do Centre d'Études en Sciences Sociales du Religieux (CéSor) EHESS em Paris.
} 
Resumo: No atual contexto pós-soviético, os altaianos estão renovando suas práticas religiosas, que se diversificaram, variando de "neoxamanismo" a "neoburcanismo", passando pelo budismo e pelo cristianismo evangélico. Dentro de cada um desses movimentos, existem músicos que se definem como kajčy (literalmente "cantor de garganta") - termo que outrora designava cantores épicos. Apresentando-se como herdeiros da arte da recitação, memorizando textos épicos, agora escritos, porém também criando suas próprias histórias correspondentes aos valores transmitidos por sua visão de mundo, para nós, esses novos bardos parecem dar uma nova vida a um gênero fortemente experimentado pelo período soviético. Nossa análise procura determinar em que medida o canto de garganta kaj, modo vocal específico por meio do qual se executa a epopeia em Altai, contribuiu para ampliar o tipo de público por quem esses textos são ouvidos, ao mesmo tempo em que passou a influenciar na transformação do relacionamento que os altaianos costumavam manter com sua herança cultural. Na primeira parte, abordaremos as características da recitação ritual de poemas épicos, as transformações sofridas durante o período soviético e a maneira pela qual o canto de garganta se insere na globalização. Numa segunda parte, focalizaremos uma recitação "à moda antiga” do bardo Èmil Terkišev. Mostraremos o papel relevante do público e o renascimento da prática da recitação, bem como o fato de os textos dos músicos responderem diretamente às expectativas do público. Numa terceira parte, a análise se concentrará em vários textos que mostram que a polifonia (Bakhtin), que Goyet demonstrou ser crucial no texto épico tradicional, atualmente é "dispersa" na multiplicidade de produções em canto de garganta.

Palavras-chave: kajčy, epopeia altaiana; epopeia dispersa.

Abstract: In a post-Soviet context, Altaian people engage new religious practices. These practices are diverse, from "neo-Shamanism" to "neo-Burkhanism", encompassing Buddhism and evangelical Christianity. Some musicians are engaged in each of these different religious movements. They present themselves as kaychi (literally "throat singer", a term which traditionally defines epic singers), and then as heirs of the tradition of epic recitation. These new bards learn epics from written texts, but also create their own, which match with their new worldview. They consequently seem to give new life to a kind of practices - one very harshly tested during the Soviet period. My analysis aims to determine to what extend the throat singing kay, the specific vocal tone employed for the recitation of epics in Altay, contributed to enlarge the public of the epics and to anew the relationship of the Altaians to their cultural patrimony. I look first at the features of the ritual recitation of epics, and at the transformations that occurred during the Soviet period. I will also present the way throat singing kay is incorporated within the framework of globalization. In a second part, I will focus on a recitation "in an olden times way" by the bard Emil Terkishev. I will demonstrate the prominent role of the auditory in the revitalization of the practices of recitation, and that the musicians sing texts which are directly answering to the public's expectations. In a third part, my analysis will provide a few texts which show that the inherent polyphony of the traditional epic text (as defined by Bakhtin), determined as crucial by Goyet when the political and social status quo is to be challenged) is nowadays "scattered" in the multiplicity of "throat sung" productions.

Keywords: kajčy, Altaian epic poetry; scattered epic.

\section{Introdução}

A poesia épica do povo altaiano passou por profundas transformações entre os séculos XIX e XXI. De fato, depois de ter sido marcada pela primeira vez pelo contato com os primeiros colonos russos e pelo cristianismo, transmitido por missionários ortodoxos, depois pelo burcanismo, um movimento religioso local que rapidamente se espalhou, a epopeia (como seus atores) enfrentou a onda da coletivização soviética. Graças ao crescente interesse pelo canto de garganta em que se baseia, a epopeia parece superar as previsões sobre seu desaparecimento e está voltando à economia de mercado da Federação Russa. 
Em um estudo anterior ${ }^{3}$, apresentamos a maneira pela qual certos textos épicos altaianos foram transformados em relação ao advento do burcanismo, na virada do século XX. Este artigo é uma continuação desse estudo, concentrando-se nas circunstâncias contemporâneas em que a epopeia é empregada em Altai. Estimamos que as diferentes produções orais em canto de garganta, atualmente acessíveis à audição, podem reivindicar serem consideradas epopeias. Com efeito, estamos diante de um caso de epopeia "dispersa", conforme definido por Florence Goyet e Jean-Luc Lambert ${ }^{4}$. Por um lado, como veremos, a reflexão realizada em 2014, em torno dessa questão, nos leva a perceber uma influência do contexto de enunciação no conteúdo dos textos. Por outro, os numerosos textos oferecidos ao ouvinte revelam as muitas possibilidades para se pensar sobre a atual identidade e a crise socioeconômica pela qual os nativos altaianos estão passando, crise iniciada pela brutal perda de marcos e valores ocorrida durante o período soviético e caracterizada por uma alta taxa de desemprego, alcoolismo na população e um forte retorno da religiosidade.

Em outros termos, parece-nos interessante questionar como as performances musicais contemporâneas, que empregam muitos critérios tradicionais de execução da epopeia, podem ser consideradas formas renovadas do épico. Para fazer isso, analisaremos as consequências de uma tentativa contemporânea de recitação épica "à moda antiga". Esse caso nos parece exemplar, em relação à influência do público sobre o texto. Em um segundo momento, ampliaremos nossa reflexão para um conjunto de textos muito significativos, cuja utilização nos parece característica das execuções épicas em Altai atualmente. Em nossa opinião, esse corpus contribui para a renovação do que F. Goyet chama de "epopeia dispersa", no qual a polifonia épica se desdobra em uma multiplicidade de produções. O fato é comum na Sibéria e, em nosso estudo anterior, já havíamos percebido essas ocorrências em Altai desde o início do século XX. Contudo, antes de chegar ao cerne da questão, apresentaremos primeiro o contexto, depois consideraremos as transformações que ocorreram no gênero durante o período soviético, antes de enfocar finalmente os vários exemplos contemporâneos significativos mencionados anteriormente.

\footnotetext{
3 JACQUEMOUD, Clément. Altaj-Buučaj, herói épico entre os dois séculos. In: Études mongoles et sibériennes, centrasiatiques et tibétaines 45, Épopée et millénarisme : transformation et innovation, section 1 : L’Épopée, un outil pour penser les transformations de la société, sous la direction de F. Goyet et J. L. Lambert, 2014, en ligne : http://emscat.revues.org/2292.

${ }^{4}$ Ver GOYET, Florence e LAMBERT, Jean-Luc. Introduction. In : Études mongoles et sibériennes, centrasiatiques et tibétaines 45, Épopée et millénarisme : transformation et innovation, section 1 : L'Épopée, un outil pour penser les transformations de la société, sob a direção de F. Goyet e J. L. Lambert, 2014. Disponível em: https://emscat.revues.org/2265), consulta em 30 de setembro de 2016. A epopeia é apresentada como "uma ferramenta para pensar as transformações da sociedade ». Ver, em particular: GOYET, Florence. De l'épopée canonique à l'épopée "dispersée" : à partir de l'lliade ou des Hōgen et Heiji monogatari, quelques pistes de réflexion pour les textes épiques notés. Disponível em: http://emscat.revues.org/2366.
} 


\section{Elementos de contextualização: os povos de Altai e suas epopeias}

Os altaianos constituem um dos cinco grupos étnicos de língua turca ${ }^{5}$ que vivem na República de Altai, uma pequena entidade administrativa na Federação Russa. Essa região está localizada nas montanhas de Altai, nos confins meridionais da Sibéria e na fronteira do Cazaquistão, China e Mongólia. Até o período soviético, os grupos étnicos altaianos tinham uma tradição épica, porém permaneceu viva apenas entre os grupos de Altai do Sul, os Altaj-kiži e os Telenguites. Atualmente, ninguém no norte da pequena região é capaz de executar nem mesmo um trecho épico.

\subsection{As características da epopeia altaiana}

As epopeias altaianas são textos longos que adotam uma estrutura métrica aliterada de versos no início de uma frase e um paralelismo sintático, narrando as fabulosas aventuras de um herói através de cenas típicas. Na maioria das línguas vernaculares turcas do sul da República (altaiano, telenguite, tchelkane, koumandine e teleoute), esses textos são geralmente chamados de kaj-čörčök ${ }^{6}$. Esse composto, que literalmente significa "conto [recitado / realizado em] canto de garganta", destaca um fator essencial, que é a técnica de execução. De fato, se os linguistas russos traduziram kaj-čörčök por epos ("épico", no sentido de "texto de tema heroico"), nenhum dos termos do composto vernacular determina essa qualidade do conto: čörčök significa em altaiano qualquer tipo de história, heroica, maravilhosa, história de animais ou outra. O termo kaj, por outro lado, que é justaposto a ele, indica a técnica com a qual a história deve ser expressamente recitada: no canto de garganta?

\footnotetext{
${ }^{5}$ A divisão desses grupos remonta ao século XIX e a distinção se baseava em critérios linguísticos, áreas de distribuição e meios de subsistência predominantes (embora não exclusivos) na época. Podemos assim distinguir grupos que vivem principalmente da caça e coleta nas florestas do norte de Altai (Toubalars, Tchelkanes e Koumandines), grupos do sul (Altajkiži e Telenguites), que são tradicionalmente considerados pastores transumanos. Os Teleoutes, que vivem no norte, fora da República, são, por sua língua e modo de vida, geralmente associados a grupos no sul. Os Chors estão linguística e culturalmente relacionados aos grupos do norte, mas também vivem fora da República de Altai, principalmente no sul montanhoso e arborizado do que é hoje o Oblast de Kemerovo. Alguns desses grupos são indígenas, enquanto outros dizem que migraram para a região apenas no início do século XVII, durante o período Dzoungare (ŠERSTOVA, Ljudmila Ivanovna, Burhanizm: istoki ètnosa i religii [Burcanismo: as fontes étnicas e religiosas]. Tomsk: Tomskij gosudarstvennyj universitet, 2010, mapa 1). O território dos altaianos foi gradualmente integrado à Rússia imperial entre 1756 e 1865, e então uma entidade administrativa autônoma nasceu na era soviética. Atualmente, cerca de um terço dos aproximadamente 200.000 habitantes da República de Altai são de etnias indígenas, enquanto a maioria da população é composta de russos que se estabeleceram na região entre os séculos XIX e XX.

${ }^{6}$ Existe uma variante semelhante em altaiano: kajlap ajdar čörčök "conto contado no canto de garganta" (PUHOV, Innokentij Vassil'evič, "Altajskij narodnyj geroičeskij èpos" [O épico popular heroico altaiano]. In: Maadaj-Kara, Altajskij geroičeskij èpos. Moscou: Nauka, 1973, p. 22). Citamos, a título de contraexemplo, o nome do épico nas línguas turcas dos vizinhos da República de Altai: em khakasse alyptyg nymah; en chor alyptyg nybak; em touva maadyrlyg tool.

${ }^{7}$ Esta técnica de canto em particular é frequentemente associada às chamadas técnicas de "canto difônico", das quais difere, no entanto, por sua "guturalidade". Reichl também fala de "vozes guturais" (REICHL, Karl. O épico oral turco da Ásia Central. In: Études mongoles et sibériennes, 32, 2001, p. 131). Em um trecho de uma epopeia cantado por um grupo de músicos contemporâneos AltajKAJ, podemos ouvir, além de uma introdução tradicional (oração ao instrumento), o canto de garganta tradicionalmente usado para recitação. Após um interlúdio de uma harpa de boca (instrumento também conhecido como trompe ou berimbau de boca), algumas passagens finais do canto difônico permitem que se sinta a diferença entre essas duas técnicas vocais. (https://www.youtube.com/watch?v=s1FVDOfGNBA).
} 
Enquanto isso, o bardo é chamado kajčy "cantor de canto de garganta" ${ }^{8}$, e seu ato de execução do texto heroico é chamado kajčy kajlap t'at, "o cantor do canto de garganta canta a canção de garganta" ${ }^{\prime}$. Portanto, essa técnica de canto em particular é muito específica e inerente ao que podemos traduzir como "epopeia". Os bardos altaianos (como os chors) geralmente acompanham sua canção épica com a melodia regular e agitada de um alaúde de duas cordas, o topšuur. O canto de garganta e o topšuur são, portanto, as características essenciais da recitação, que tornam a canção épica ${ }^{10}$.

Nas sociedades da área mencionada, que são altamente patrilineares e virilocais, ser bardo é um status que é transmitido na linhagem do pai ${ }^{11}$. No entanto, acredita-se, é o caso de alguns bardos

8 Dyrenkova esclareceu sobre os Chors: "contadores de histórias particulares, os kajčy cantam poemas heroicos e cada um
tem seu próprio repertório e maneira de cantar" (DYRENKOVA, Nadežda Petrovna. Šorskij Fol'klor [Coro folclórico]. Moscou:
Léningrad, Izdatel'stvo Akademii Nauk SSSR, 1940, p. XXXVII). O sufixo -čy é geralmente um sufixo especial ou profissional
(BASKAKOV, Nikolaj Aleksandrovič \& TOŠčAKOVA, Taisija Makarovna. Ojrotsko-russkij slovar' [Dicionário Oirote-Russo],
Moscou: OGIZ, Gosudarstvennoe Izdatel'stvo Inostrannyh i Nacional'nyh Slovarej, [1947] 2005, p. 242; 245). Kajčy é, portanto,
literalmente o "especialista em canto de garganta".
${ }^{9}$ Entretanto, existem outras expressões para descrever o ritual entre os povos vizinhos, como em chor: nybaq salarya ("largue
o conto") ou nybaq yzarya ("envie o conto") (DYRENKOVA. Šorskij Fol'klor. op cit., p. XXXVII). Embora esteja amplamente
presente na área turco-mongol, o canto de garganta não era usado em todos os lugares para recitar o épico: contos épicos
podiam ser recitados sem uma voz de garganta (como procedem os bardos altaianos Tabar Čačijakov e Saldabaj Savdin).
Contudo, essa maneira de usar os textos não foi valorizada, pois as mulheres poderiam muito bem recitar dessa maneira (ver
nota 9). "O épico em que a voz de garganta é usada e, às vezes, apresenta intencionalmente harmônicos, é encontrado nas
práticas quirguizes, khakasses, kalmoukes, turcomanas, azerbaidjanas, e entre os cazaques e os Karakalpaks do Uzbequistão",
especifica J. Curtet (CURTET, Johanni. La transmission du höömij, un art du timbre vocal : ethnomusicologie et histoire du
chant diphonique mongol. Tese de doutorado, sob a supervisão de Alain Desjacques. Rennes: Universidade Rennes 2, 2013, p. 139).

10 O topšuur é um instrumento de cordas dedilhadas, cujo nome pode derivar do mongol tovših "fazer vibrar, dedilhar" (CURTET. La transmission ..., op. cit., p. 200). Cumpre observar que a melodia repetida, usada para acompanhar recitações épicas, é frequentemente descrita como "monótona" por etnomusicólogos (REICHL, O épico oral..., op. cit., p. 137). Essa "monotonia", comparada à surpreendente originalidade dos rituais xamânicos, pode ser a razão do interesse tardio na performance do ritual épico e nos textos. Os contadores de histórias chors kajčy recitavam os épicos acompanhados por um kaj komys, um alaúde em todos os aspectos semelhante ao topšuur dos altaianos (DYRENKOVA, Šorskij Fol'klor, op. cit., p. XXV). Certos grupos, porém, não fazem desse modo: assim os grupos dos bouriates, khakasses ou mongóis. Os Buryats são grupos de falantes da língua mongol que vivem nas margens do Lago Baïkal. Embora eles também usem o canto de garganta, seus bardos originalmente realizam o épico sem nenhum acompanhamento, ou mais tardiamente, o fazem usando um huur antigo (HAMAYON, Roberte. La chasse à l'âme - Esquisse d'une théorie du chamanisme sibérien [A Caçada à alma - Esboço de uma teoria de xamanismo siberiano]. Nanterre: Sociedade de Etnologia, 1990, p. 171-174). Os khakasses são grupos de falantes da língua turca (Katchines, Sagaïs, Koïbales, Beltires e Kyzyles) que vivem na República da Khakassia, a qual faz fronteira com a República Altai. Conquanto eles também pudessem usar um topšuur, seus bardos hajdžy geralmente recitavam seus épicos acompanhados por uma cítara čatkan colocada sobre os joelhos (BUTANAEV, Viktor Jakovlevič \& BUTANAEVA, Irina Isaevna. Hakasskij istoričeskij fol'klor [O folclore histórico khakasse], Abakan, 2001; MAJNOGAŠEVA, Valentina Evgen'evna. Hakasskij geroičeskij isès "Altyn-Aryg" [O épico heróico khakasse "Altyn-Aryg"]. In: Altyn-Aryg, Hakasskij geroičeskij èpos. Moscou: Nauka, 1988, p. 498-499; STOJANOV, Anatolij Konstantinovič. Isskustvo hakasskih hajdži [A arte dos hajdži khakasses]. In: Altyn-Aryg, Hakasskij geroičeskij èpos. Moscou: Nauka, 1988, p. 577). Para recitar suas epopeias, os mongóis usam uma voz diferente chamada argil (CURTET. La transmission..., op. cit., p. 130) e acompanham sua canção com o violino "com a cabeça de cavalo" morin huur (ou hiil huur; MARSH, Peter K. The Horse-head Fiddle and the Cosmopolitan Reimagination of Tradition in Mongolia. Nova York, Londres: Routledge, 2009, p. 27), encontrados em Altai sob o nome de ikili (o objeto não tem o mesmo trabalho ornamental, no entanto). Diz-se que uma história executada sem uma canção de garganta ou um instrumento é recitada "a pé" (ver nota 7). Somente contos executados a cavalo, portanto cantados e acompanhados por um topšuur, têm uma eficácia simbólica. Veremos mais adiante quais eram especificamente os efeitos esperados, quando o canto era executado dessa forma.

${ }^{11}$ Diz-se que a voz particular do bardo passa de geração em geração e, portanto, quem o transmite não pode mais cantar (HARVILAHTI, Lauri. Altai Oral Epic. In: Oral Tradition, 15, 2, 2000, p. 218), até morrer (FUNK, Dmitri Anatol'evič. Miry šamanov i skazitelej. Kompleksnoe issledovanie teleutskih i šorskih materialov [Os mundos dos xamãs e dos bardos. Estudo complexo de materiais dos teleoutes e dos chors]. Moscou: Nauka, 2005, p. 261). Em Altai, o bardo que recita o canto de 
nessa área, que a voz singular e o instrumento acompanhante, às vezes o próprio texto, são recebidos dos espíritos ${ }^{12}$. Esses bardos, em contato com esse mundo espiritual que R. Hamayon chama de "sobrenatural"13, são considerados èèlü-kajčy [mestres contadores de histórias]. Assim, nessa sociedade, que tem uma visão xamânica do mundo, a ênfase é colocada no vínculo particular que une certos artistas e o mundo espiritual. Quando o bardo canta, a voz que ele usa não é a sua voz natural. Essa voz permite que ele entre em contato com os espíritos ${ }^{14}$, porém também permite afirmar que um espírito se expressa através dele e o inspira a cantar.

Portanto, antes da era soviética, a epopeia não era um texto que se podia cantar levianamente, pois sua recitação envolve forças sobrenaturais. E, como em qualquer sociedade xamânica, os espíritos não devem ser invocados sem motivo. As expectativas estão associadas à

garganta deve ser necessariamente um homem, por várias razões. Por um lado, a técnica vocal contribuiu para a eficácia do ritual. A história mantém o nome de muitos contadores de histórias (KONUNOV, Arkadij. Altajdyn Kajčylary - Kajčy Altaja [Os kajčy de Altai]. Gorno-Altaïsk: Ministerstvo Kul'tury Respubliki Altaj, Respublikanskij Centr Narodnogo Tvorčestva, NauatnoIssued Altaistiki im SS Surazakova, 2010, 68 p.), E Funk (Miry šamanov ..., op. cit., P. 277-278), entre os Chors, costuma-se falar de "meio épico", quando são citadas mulheres que conhecem os textos, sabem recitá-los e são direta ou indiretamente ligadas aos bardos (esposa, filha ou irmã). Entre os mongóis, Pegg (PEGG, Carole. Ritual, Religion and Magic in West Mongolian (Oirad) Heroic Epic Performance. In: British Journal of Ethnomusicology, Vol. 4, 1995, p. 90) lembra que algumas mulheres conheciam histórias, tinham participado do treinamento do marido ou tinham contribuído com o treinamento dos filhos. Contudo, em todos os casos, a técnica vocal para recitar a epopeia, o canto de garganta, não foi (e ainda não é) recomendada para elas: entre os mongóis, além de sua suposta incapacidade física (Curtet, A transmissão ..., op. cit. p. 345; ideia compartilhada pelo khakasses: STOJANOV, "Isskustvo ...", op. cit., p. 581-582), o perigo geralmente temido era infertilidade (PEGG, Carole. Mongolian Conceptualisations of Overtone Singing (xoomii). In: British Journal of Ethnomusicology, Vol. 1, 1992, p. 43-44). Durante minha pesquisa em Altai, apesar de me lembrar de que eles tiveram seus filhos e não estavam mais arriscando nada naquele nível, os "músicos" entrevistados enfatizaram o perigo da infertilidade acima de todos os efeitos sociais (arquivo particular) de sua prática do cantar de garganta (RM, testemunho gravado em 01/02/2011 em Gorno-Altaïsk; N. O. È., Depoimento registrado em 25/07/2012). De modo que, para voltar à eficácia do ritual, os caçadores, quando vão recitar a epopeia, nunca levam uma mulher para caça. Durante nossa pesquisa de mestrado, levantamos a hipótese de que essa proibição poderia estar ligada à participação de clãs em territórios de caça: "conceder o direito de cantar [o épico] a uma mulher que vem de outro clã é deixar para ela as 'rédeas' na obtenção da sorte com a caça, pois ela estabelecerá uma relação com o espírito mestre dos lugares do clã do marido" (JACQUEMOUD, Clément. Barde et chamane, Étude anthropologique comparative de deux spécialistes rituels en République d'Altaï (Sibérie méridionale) [Bardo e xamã, Estudo antropológico comparativo de dois especialistas em rituais na República de Altai (sul da Sibéria)]. Tese de mestrado II. Paris: Escola Prática de Estudos Avançados, 2009, p. 83-84). Segundo J.-L. Lambert (comunicação pessoal), uma mulher não pode trazer sorte à caça. Segundo R. Hamayon, a proibição de caçar acompanhado de mulheres está ligada ao sangue menstrual (HAMAYON. La chasse..., op. cit., p. 392-395), e "as meninas só podem conhecer a epopeia, se for necessário que elas a conheçam, para transmiti-la por sua vez; porém, na véspera da caça ao cervos, elas não devem executá-la ritualmente, ou seja, não devem "chamá-la", quer dizer: não devem invocar os heróis épicos para a comunidade" (op. cit., p. 176). A questão da prática feminina de recitar a epopeia, que vai além da estrutura deste artigo e sobre a qual estamos trabalhando em outros lugares, consiste, portanto, em esclarecer se é o uso do texto como tal ou a técnica da execução performática que provavelmente prejudicará a mulher que está executando o canto ou mesmo toda a comunidade.

12 ŠEJKIN, Jurij II'ič e NIKIFOROVA, Vera Semenovna. Altajskoe èpičeskoe intonirovanie" [A entonação épica altaiana]. In: Altajskie geroičeskie skazanija. Novosibirsk: Nauka, 1997, p. 51; FUNK, Miry šamanov..., op. cit., p. 366. Com efeito, os espíritos, freqüentemente percebidos nos sonhos, podem oferecer "cordas vocais de cobre" ou, em certos casos em que o "destino" está em jogo, escolher entre os atributos do xamã e do bardo (BUTANAEV, Viktor Jakovlevič. Tradicionnyj šamanism Xongoraja [O xamanismo tradicional de Khongoraï]. Abakan: Izd-vo Hakasskogo Gosudartsvennogo Universiteta im NF Katanova, 2006, p. 62; FUNK. Miry šamanov..., op. cit., p. 264-265). Assim, um cantor khakasse disse que tinha a opção de escolher entre uma roupa de xamã e instrumentos musicais. Segundo ele, se tivesse escolhido o tambor, ele se tornaria um xamã, o que prova de que maneira a epopeia e o xamanismo podem estar ligados na Sibéria (Funk, idem).

13 HAMAYON. La chasse..., op. cit., p. 331-332.

${ }^{14}$ LEBENDINKSIJ, Lev Nikolaevič. Isskustvo uzljau u baškir [A arte dos uzlau entre os Bachkires]. In: Sovetskaja Muzyka, 4, 1948, p. 51, citado por Stojanov, "Isskustvo ...", op. cit., p. 578. 
recitação épica, como a chance de caçar ou de se recuperar de uma doença ${ }^{15}$. Eles colocam em contato o mundo espiritual e o mundo dos homens e devem se beneficiar das melhores condições a serem cumpridas. Em toda a área turco-mongol, as regras em torno da recitação são numerosas: só pode ocorrer à noite, durante a estação fria, mais precisamente após o aparecimento da constelação das Plêiades no céu noturno ${ }^{16}$. Segundo Šejkin e Nikiforov, nenhum ritual xamânico deve ser realizado paralelamente a outro evento ${ }^{17}$.

Outra regra muito importante é que a epopeia deve ser cantada por inteiro. $\mathrm{O}$ bardo pode ser penalizado se ele não cantar o texto completo ou omitir certas partes ${ }^{18}$. Os espíritos que deram voz ao bardo Tortobaev acrescentaram: "Não encurte as epopeias. Se você cantar apenas a metade do canto, nós encurtaremos sua vida"19. Para outro bardo, eles dizem: "O herói do seu conto não voltou para casa, ele ainda está no topo da montanha. Você já contou muitas histórias sem terminá-las, já deixou muitos heróis com dor, agora vai morrer!"20. Heróis épicos também são vistos como entidades sobrenaturais capazes de honrar e punir o bardo. Como em uma cerimônia xamânica, eles não podem

\footnotetext{
${ }^{15}$ HAMAYON. La chasse..., op. cit., p. 182-183; Funk, Miry šamanov..., op. cit., p. 253; Šejkin e Nikiforov, "Altajskoe ...", op. cit., p. 54; materiais de campo 2011. O bardo altaiano Akčabaj Markov, convocado para a Segunda Guerra Mundial, relatou ter cantado épicos para se tranquilizar e ser protegido de balas durante os combates (ŠEJKIN e NIKIFOROV, "Altajskoe...", op. cit., p. 54). ). Guerra e outras calamidades são, nas palavras de Bardo Saldabaj Savdin, as condições para o aparecimento de kaj (ŠEJKIN e NIKIFOROV. "Altajskoe ...", op.cit., p. 52). Em certo sentido, isso se vincula às hipóteses de F. Goyet em relação às situações que favorecem o surgimento do épico: "Quando colocamos as epopeias em seu contexto histórico", o primeiro resultado é perceber que o mundo onde eles se desenvolvem é abalado por uma intensa crise política" (GOYET, Florence. L'épopée. In: Vox Poetica, 2009, online: http://www.vox-poetica.org/sflgc/biblio/goyet.html, acesso em 10/10/2013).

${ }^{16}$ HAMAYON. La chasse..., op. cit., p. 167, para os Buryats. As epopeias dos Buryat são chamadas üliger (ou ül'ger, ülger), um termo que significa "modelo, exemplo". É sabido que a época do ano em que os Buryats cantam epopeias é a estação fria. Todavia, o fato de ülger ser o nome da constelação das Plêiades em altaiano [e mais geralmente em turco comum, de acordo com L. Bazin (BAZIN, Louis. Les systèmes chronologiques dans le monde turc ancien [Sistemas cronológicos no antigo mundo turco]. Budapeste: Akadémiai Kiadó, Paris: Edições do CNRS , 1991, p. 504)], nos leva a crer que os épicos altaianos devem ter sido recitados ao mesmo tempo. Ülger sös (lit. "palavra sábia") significa "provérbios" em altaiano. Composto por apenas duas linhas, eles geralmente entram na composição de poemas épicos. Aqui encontramos a idéia de sabedoria e exemplaridade transmitida pelos épicos, e a observação feita pelo kajčy Nogon Šumarov sobre eles ("eles contêm muita sabedoria") assume então seu significado completo (entrevista 03/2007) .

17 Embora geralmente sejam percebidos como opostos (BUTANAEV. Tradicionnyj šamanism ..., op. cit., p. 64; ŠEJKIN e NIKIFOROV, "Altajskoe ...", op. cit., p. 53), xamãs e bardos são assistidos pelos mesmos espíritos auxiliares tös (FUNK, Miry Šamanov ..., op. cit., p. 265), e, entre os Chors, os antigos xamãs podiam se tornar bardos (DYRENKOVA. Šorskij fol'klor, op. cit., p. 441). Contudo, de acordo com A. G. Kalkin (ŠEJKIN e NIKIFOROV, idem), os dois especialistas não devem realizar rituais ao mesmo tempo. De fato, a história contada pelo bardo provavelmente agradará os espíritos auxiliares do xamã (da mesma maneira como esses espíritos inspiram o canto para os destinatários da epopeia). O xamã, portanto, corre o risco de não encontrar o caminho e falhar em recuperar o mundo dos homens se seu espírito não estiver presente para ajudá-lo (JACQUEMOUD. Bardo e xamã..., op. cit).

${ }^{18}$ BUTANAEV. Tradicionnyj āamanism..., op. cit, p. 63; DYRENKOVA. Šorskij fol'klor, op. cit., p. XXXIX; FUNK. Miry šamanov..., op. cit., p. 266; HARVILAHTI, Lauri. The Holy Mountain. Studies on Upper Altay Oral Poetry. Helsinque: Suomalainen Tiedeakatemia Academia Scientiarum Fennica, 2003. Durante uma noite na casa de um amigo Kajčy convertido ao protestantismo evangélico, ele se ofereceu para ser gravado recitando a epopeia de Očy-Bala aprendida em um livro. Já era tarde, eu estava pensando em ir para a cama, porém o interesse óbvio pela proposta me deu coragem. Então ele começou a tocar o topšuur, enquanto eu virava as páginas do livro que ele estava lendo, à medida que cantava. Depois de mais de mil linhas de recitação lenta e monótona, quase sendo abandonado pelas minhas últimas forças, esqueci de virar as páginas enquanto meu amigo me empurrava regularmente para me acordar. Fiquei me perguntando quanto tempo isso iria durar quando finalmente parasse. Ele justificou a duração de sua execução pelo fato de não poder terminar seu canto até ter trazido a heroína de volta para casa para fazê-la dormir.

${ }_{19}$ FUNK. Miry šamanov..., op. cit., p. 344.

${ }^{20}$ BUTANAEV. Tradicionnyj āamanism..., op. cit, p. 63.
} 
ser invocados sem nenhuma razão e é necessário lhes agradecer e conduzi-los de volta ao lar, depois de invocá-los.

A concordância de regras estritas torna a recitação do texto heroico um ritual, um processo cuja eficácia é esperada. Enfim, devemos salientar que, como os heróis das epopeias de Buryat analisados por R. Hamayon, os quais por sua diversidade sugerem que "as epopeias, em vez de apenas representarem uma norma ideal, são a representação do princípio de um padrão ideal de uma sociedade ou comunidade"21, a epopeia altaiana transmite valores e regras que devem ser inspirados e, por conseguinte, podem assumir um significado identitário para aqueles que o cantam. Vamos agora ver até que ponto o épico poderia ter desempenhado um papel significativamente unificador em Altai no século $X X$.

\subsection{A epopeia no início do século 20 , uma mudança de forma e conteúdo}

O início do século XX viu o surgimento de um movimento messiânico e milenar em larga escala entre os nativos de Altai chamado burcanismo, termo derivado do nome da então venerada divindade Ak-Bourkhan. Diz-se que essa divindade se dirigiu aos nativos de Altai através de seu mensageiro Ojrot$K^{K h a n}{ }^{22}$. O surgimento do movimento levou à expulsão dos xamãs que estavam à frente da cena religiosa. Os bardos se tornaram extremamente importantes dentro da nova corrente religiosa, tanto que alguns se tornaram t'arlykčy, "mensageiros". Esses personagens, que têm o status de sacerdote, conduziam os rituais. Eles estavam em contato com as novas divindades ou espíritos do movimento, como Ak-Bourkhan, e seus enviados Ojrot-khan, Khan-Altaj e outros, de quem eles disseram ter recebido textos de louvor $(a \mid k y s ̌)^{23}$. Sua prática do canto de garganta acompanhado do alaúde topšuur, critérios essenciais para a performance épica, foi estendida a esse novo contexto religioso para a recitação dessas orações de bênção, muitas vezes imbuídas de um forte tom lírico. Convém notar que, como S. Jacquesson indica para os Quirguizes, não há também em Altai “diferença formal entre o verso épico e o de canções ou lamentações líricas, por exemplo". Daí uma forte porosidade entre os estilos

\footnotetext{
21 "The very existence of different types of heroic models suggests that the epics represent the principle of an ideal norm of a society or community rather than a particular ideal norm, since the details of the norm may change from one type to another" (HAMAYON, Roberte. The Dynamics of the Epic Genre in Buryat Culture - a Grave for Shamanism, a Ground for Messianism. In: JANSEN, Jan \& MAIER, Henk M. J. (éd.). Epic Adventures - Heroic Narrative in the Oral Performance Traditions of Four Continents. Münster: LIT Verlag, 2004, p. 56-57).

${ }^{22}$ Analisando a figura lendária de Ojrot-khan, percebemos que ela personifica os khans do "império" de Oirate (ou Khanat dzoungar, 1616-1756) cujos feitos são transmitidos de geração em geração (ZNAMENSKI, Andrei. Power of Myth: Popular Ethnonationalism and Nationality Building in Mountain Altai. 1904-1922. In: Acta Slavica laponica, 22, 2005, p. 31). AkBourkhan significa "Buda branco" ou "divindade branca" em mongol. Burcanismo é o nome russo dado ao movimento, ao passo que, entre os nativos, ele é chamado Ak-T'an ("Fé / Maneira de fazer branco") ou Altaj-T'an ("Fé / Maneira de fazer altaiana"). Convém observar, a esse respeito, que os altaianos, diferentemente de seus vizinhos mongóis ou touvas, não foram tão intensamente convertidos ao budismo ao longo da história. É por isso que o nome Bourkhan está associado em Altai apenas ao movimento religioso burcanista. Ak-Bourkhan e Ojrot-khan são figuras algumas vezes completamente assimiladas entre si.

${ }^{23}$ Os textos foram "recebidos" na forma de orações recitadas durante os rituais. Podemos perceber essa prática, ainda em andamento no movimento contemporâneo, como um caso típico de canalização.
} 
épico e lírico, podendo as "ferramentas poéticas" 24 serem aplicadas indiferentemente a um ou outro gênero.

O movimento burcanista é marcado em grande parte pelo nacionalismo. De tal modo que, em uma canção de louvor dedicada a Ojrot-Khan, o mensageiro é apresentado como um herói por vir, que virá combater os russos, devolver Altai aos altaianos e libertá-los da condição de colonos ${ }^{25}$. Embora o texto seja mais curto que um poema épico, a maneira como a divindade é encenada evoca claramente os heróis épicos ${ }^{26}$ : da figura difusa do herói histórico nasce a divindade, que por sua vez é heroica.

Ao mesmo tempo, os textos épicos refletem cada vez mais a influência de movimentos religiosos concorrentes na região (burcanismo, cristianismo, e em menor grau, budismo). Observamos, portanto, transformações na representação de certos heróis: ainda que sejam sempre vistos como salvadores de um povo oprimido, eles assumem a forma de Messias investidos com a missão de libertar seus contemporâneos do jugo de um colonizador ${ }^{27}$. Também notaremos a passagem de um tempo épico para o presente, marcado pelo envolvimento do bardo com o seu público, através do uso de um "nós" coletivo.

\subsection{O período soviético, ou o desaparecimento progressivo de uma tradição}

Durante o período soviético, muitas mudanças ocorreram na prática da recitação. Os bardos que antes podiam ser convidados por diferentes clãs, em função de sua fama, também sofreram os efeitos da coletivização e contribuíram na construção do socialismo. Os mais famosos tornaram-se figuras emblemáticas do regime, apesar das deficiências físicas que afetam muitos deles, as quais levaram aqueles que as tinham a serem considerados impróprios para o trabalho - pois a constituição física era um critério essencial na URSS. Por exemplo, em reconhecimento à sua contribuição para o esforço comunista, os bardos altaianos N. U. Ulagašev e A. G. Kalkin foram convidados a Moscou para serem condecorados ${ }^{28}$.

\footnotetext{
24 JACQUESSON, Svetlana. Les bardes kirghiz: initiations, apprentissages, pratiques [Bardos quirguizes: iniciações, aprendizagens, práticas]. Comunicação durante o seminário de Revel, Nicole e Servan-Schreiber, Catherine. Les épopées : littératures de la voix. Apprentissages et fonctions [As epopeias: literaturas da voz. Aprendizagens e funções]. Paris: Centro de Pesquisa em Oralidade, 1999, p. 14.

25 DANILIN, Andrej Grigor' evič. Burhanizm, Iz istorii nacional'no-osvoboditelnogo dviženija contra Gornom Altae [Burcanismo. História de um movimento nacional libertador na Altai montanhosa]. Gorno-Altaïsk: Ak Čeček, 1993, p. 95.

${ }^{26}$ Também é possível citar um texto coletado por A. G. Danilin, intitulado Prière à tous les esprits-héros [Oração a todos os espíritos-heróis] (Molitva vsem duham bogatyrjam), dirigido às diferentes divindades dos panteões xamânicos e burcanistas altaianos (ŠUNU, Ojrot. Ülgen, Üč Kurbustan...), mas também aos heróis épicos (Altan Topčy, Ak Ančy, Gezer...) e até ao imperador Constantino! (Arquivos A. G. Danilin, do Instituto de Etnografia N. Mikluho-Maklaj da Academia Russa de Ciências, f. 15, p. 413, ano de 1927-1936, op. 1, ed. Khr. 10).

27 JACQUEMOUD. "Altaj-Buučaj, ...", op. cit.

${ }^{28}$ Assim, o bardo N. U. Ulagašev recebeu em 1939 o "Distintivo de Honra" (russo Znak Počëta) (DEMČINOVA, Mira. Alčinovna, Vvedenie [Introdução]. In: Skazitel 'Nikolaj Ulagašev: Altajskie geroičeskie skazanija. Gorno-Altaïsk: Ministerstvo Kul'tury Respubliki Altaj, Gosudarstvennoe naučnoe učreždenie Respubliki Altaj “Naučno-Issledovatel'skij Institut Altaistiki im. S. S. Surazakova", 2011, p. 9), que reconhece conquistas no campo da literatura, enquanto A. G. Kalkin foi condecorado em 1948 com uma distinção honorária (russo Počëtnaja gramota) (SURAZAKOV, Sazon Sajmonovič. Biografija skazitelja A.G. Kalkina [Biografia do bardo A. G. Kalkin]. In: Maadaj-Kara, Altajskij geroičeskij èpos. Moscou: Nauka, 1973, página 441; Šinžin,
} 
Muitos folcloristas também procuraram os bardos para escrever seus textos. A "pesquisa folclórica" (russo fol'kloristika) desse período, embora seja antes de mais nada uma continuação da ciência folclórica da era pré-revolucionária, não demorou muito para percebê-los como pessoas influentes e tentar usá-los como um meio de propaganda ${ }^{29}$. Assim, Ulagašev e Kalkin, para citar apenas alguns, produziram canções para a glória dos heróis do Partido (Lenin e Stalin em particular), sobre os temas da guerra ou glorificando os sucessos do país ${ }^{30}$.

Por outro lado, os textos épicos coletados durante esse período podem ser bastante diluídos, devido à sua potencial falta de relevância para a visão soviética. Em sua atividade como folclorista, o kajčy T. B. Šinžin esteve em contato com os últimos grandes bardos altaianos ${ }^{31}$ e, segundo ele, esses bardos passavam a se autocensurar, quando percebiam que o assunto da conversa se tornava ofensivo ou inadequado ao contexto político ${ }^{32}$ (entrevista realizada em 01/01/2011).

Se o conteúdo dos textos mudou, o papel das barreiras, o contexto de execução e o modo de transmissão também mudaram. Passando da tenda para o palco, os especialistas em rituais gradualmente ganharam o status de artistas, o que se reflete tanto em suas viagens quanto nas decorações, mas também na maneira como agora usavam seus textos. De fato, ainda que tenham sido convidados a recitar durante simpósios pela URSS ou no âmbito de pesquisas em institutos, sua prática foi então vista como completamente desconectada do contexto muito particular que contribuiu para sua especificidade (épico recitado à noite, inverno, na íntegra, enfrentando um grande público etc.). Por outro lado, a ênfase dada à singularidade vocal na execução do canto levou à folclorização deste último: enquanto a prática do canto de garganta, acompanhado do alaúde topšuur, começou a ser

Ivan (Tanispaj) Boksurovič, Skazitel' A.G. Kalkin [O bardo A. G. Kalkin], Gorno-Altaïsk, Gorno-Altajskij Naučno-Issledovatel'skij Institut Istorii, Jazyka i Literatury, 1987, p.17). Kalkin também se apresentou várias vezes no palco e seus textos foram coletados pelos turcologistas V.A. Gordlevskij e N. A. Baskakov durante sua performance na Casa Pan-Soviética de Criação Popular (Vsesojuznyj dom narodnogo tvorčestva im. N. K. Krupskoj; Surazakov, idem).

${ }^{29}$ Sobre o papel dos folcloristas soviéticos durante o período stalinista, pode-se fazer referência ao artigo de T. G. Ivanovna (IVANOVNA, Tatiana Grigorievna. Literatura oral narrativa e seu uso no período stalinista. In: Etnologia francesa, XXVI, 4, 1996 727-737).

${ }^{30}$ SURAZAKOV. “Biografija ...", op. cit., p. 442. Aqui está um trecho de uma canção partidária do bardo N. U. Ulagašev (original em russo):

$\checkmark$ nebe ptica letit

S blestjaščimi stal'nymi kryl'jami

Mudryj, velikij Stalin

Poslal eë k nam na Altaj

No céu um pássaro voa

Com asas de aço brilhantes

O sábio e grande Stalin

Nós o enviamos para Altai

(KOPTELOV, Afanasij Lazarevič. Kajčy N. U. Ulagašev [O kajčy N. U. Ulagašev]. In: Sibirskie ogni, 1, 1941, p. 130).

Podemos ver que, nesse contexto, os textos que comemoram os heróis do Partido estão alinhados com os textos burcanistas, em particular através do uso de um "nós" coletivo.

31 T. B. Šinžin não é o único folclorista altaiano a ser considerado um bardo: foi precedido em particular por P. V. Kučijak (1897-1943) e S. S. Surazakov (1925-1980).

32 Inspirado pelas observações de Reynolds sobre os bardos do Egito (REYNOLDS, Dwight F. Heroic Poets, Poetic Heroes: The Ethnography of Performance in an Arabic Oral Epic Tradition. Ithaca: Cornell University Press, 1995, 304 p.), K. Reichl apontou que os bardos da Ásia Central poderiam muito bem "modificar a narrativa para chamar a atenção dos ouvintes ou fazer comentários sobre eles. Se alguém adormece durante a recitação, o bardo faz o herói adormecer e depois o acorda com gritos, o que, é claro, também acorda o ouvinte adormecido” (REICHL, “O épico oral... ”, op. cit., p. 129). 
ensinada nas escolas de música, foram feitas tentativas para integrá-los nas orquestras clássicas ${ }^{33}$. A técnica teve precedência sobre o texto, enfatizando o virtuosismo musical, em vez do conhecimento de milhares de versos da poesia épica.

Consequentemente, a prática da recitação épica durante o período soviético, que podemos considerar como um tipo de prática musical, é "extraída de seu contexto comum e transposta no palco". E essa música, "não é executada fora de uma determinada estrutura, ou seja, não é executada em um espaço neutro e privado de referências; ao contrário, de fato ela é executada em um novo contexto: um contexto para o qual a performance foi reformatada e, de certa forma, higienizada para atender aos códigos e padrões de sua representação cênica" ${ }^{34}$. Nessa lógica de adaptação, a prática será acompanhada de transformações em todos os níveis. De modo que, diante da chegada da eletricidade, rádio e Centros culturais, e após a coletivização que manteve os "trabalhadores" afastados das atividades de caça, os altaianos passaram a se sentir menos inclinados a se reunirem em torno dos bardos $^{35}$. Com a diminuição progressiva de sua audiência, a prática de execução épica declinou, o número de cantores épicos diminuiu e o importante trabalho de memorização foi interrompido. Os textos, que anteriormente, depois de escritos, eram transmitidos de forma oral, desapareceram gradualmente, assim como os bardos foram sendo substituídos por artistas-músicos e a fatura dos instrumentos tradicionais começou a ser retrabalhada e adaptada aos objetivos cênicos ${ }^{36}$.

\footnotetext{
${ }^{33}$ As primeiras tentativas datam da década de 1930 (HOHOLKOV, Vladimir Fedorovič. Muzykal'nye instrumented Gornogo Altaja [Os instrumentos musicais da Altai montanhosa., Gorno-Altaisk, 2004, p. 8).

${ }^{34}$ AUBERT, Laurent. Como expor a música e o que ela diz. In: DESROCHES, Monique, PICHETTE, Marie-Hélène, DAUPHINE, Claude, SMITH, Gordon E. (ed.). Territoires musicaux mis en scène. Montreal: Imprensa da Universidade de Montreal, 2011, p. 23, para ambas as citações.

${ }^{35}$ Convém lembrar também que os bardos foram convidados a tocar pelo baj (gente rica e notável) (KALAČEV, A.. Neskol'ko slov o poèzii telengitov [Algumas palavras sobre a poesia dos telenguites]. In: Živaja Starina, 3- 4, 1896, p. 490). De modo que todos se reuniam em torno desse baj anfitrião para ver e ouvir o rapsodo, que às vezes vinha de muito longe e, por isso, passava vários dias no acampamento. Em relação aos quirguizes, Radloff (RADLOFF, Friedrich Wilhelm. Proben der Volkslitteratur Dernördlischen Stämme: Theil V [Amostras de literatura popular das tribos do norte]. São Petersburgo, 1885, citado por JACQUESSON, "Les bardes...", op. cit. , p. 2) relata que, além de sua proteção, do fornecimento da alimentação e do abrigo, o anfitrião geralmente oferecia ao bardo um cavalo como forma de recompensá-lo pelo seu trabalho, e o entusiasmo desse baj podia mesmo levá-lo, como ocorria às vezes, quando ele se encontrava sob o efeito fascinante da recitação, a jogar seu casaco no bardo.

36 Segundo Hoholkov (Muzykal'nye ..., op.cit., p. 8), a modernização do instrumento ocorreu em 1939-1940 sob a responsabilidade de P. A. Šošin. Notaremos, em particular, a presença de trastes, nylon ou mesmo cordas de metal, no lugar de cordas de crina de cavalo, e uma fina placa de madeira no corpo do instrumento, em vez de uma membrana de pele de veado.
} 


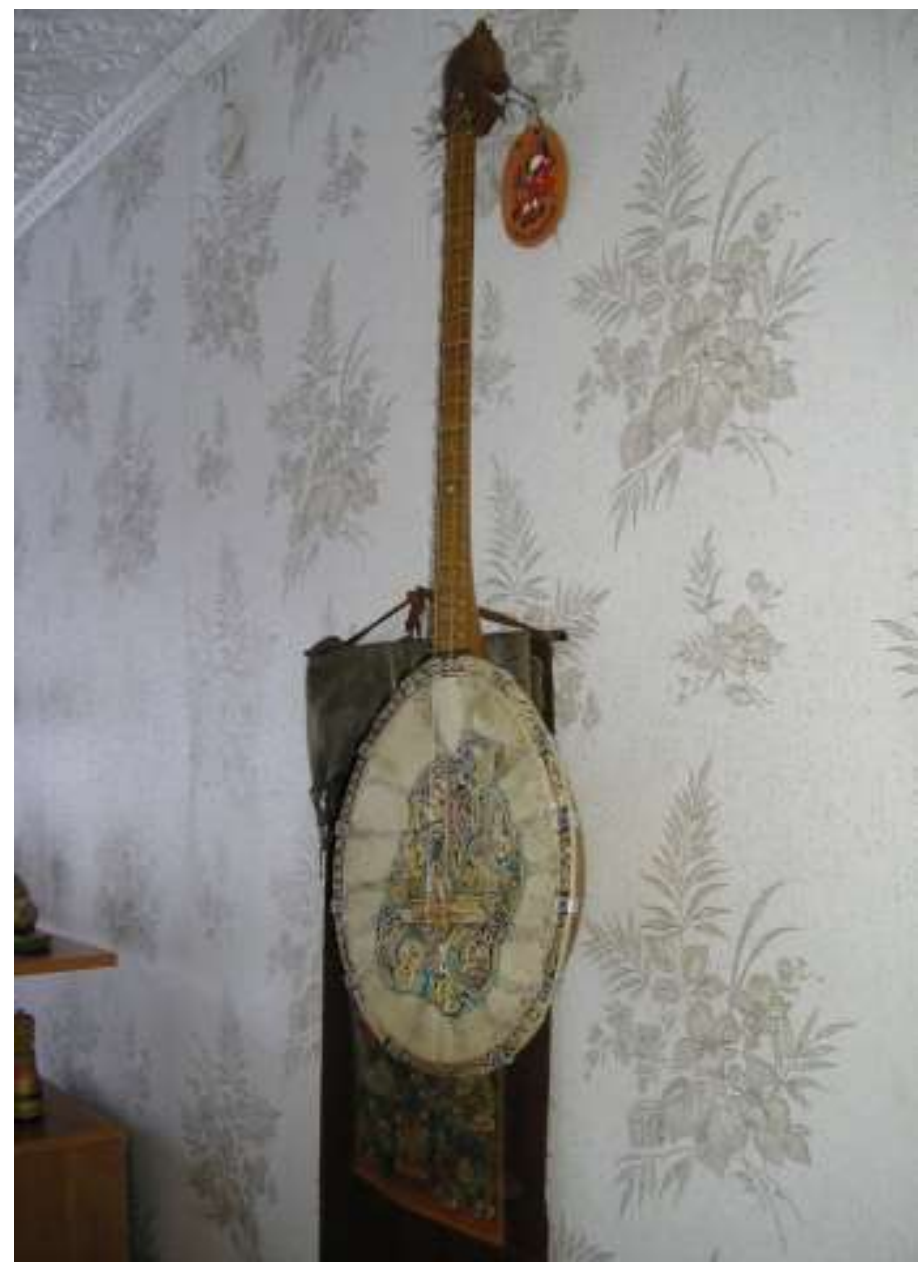

Dois topšuur trabalharam para destacar sua etnia

(acima o de N. Šumarov, coberto com uma pele "decorada por um xamã", e abaixo, nas mãos de kajčy A. Turlunov, uma obra de A. Ènčinov, renomado músico e luthier)

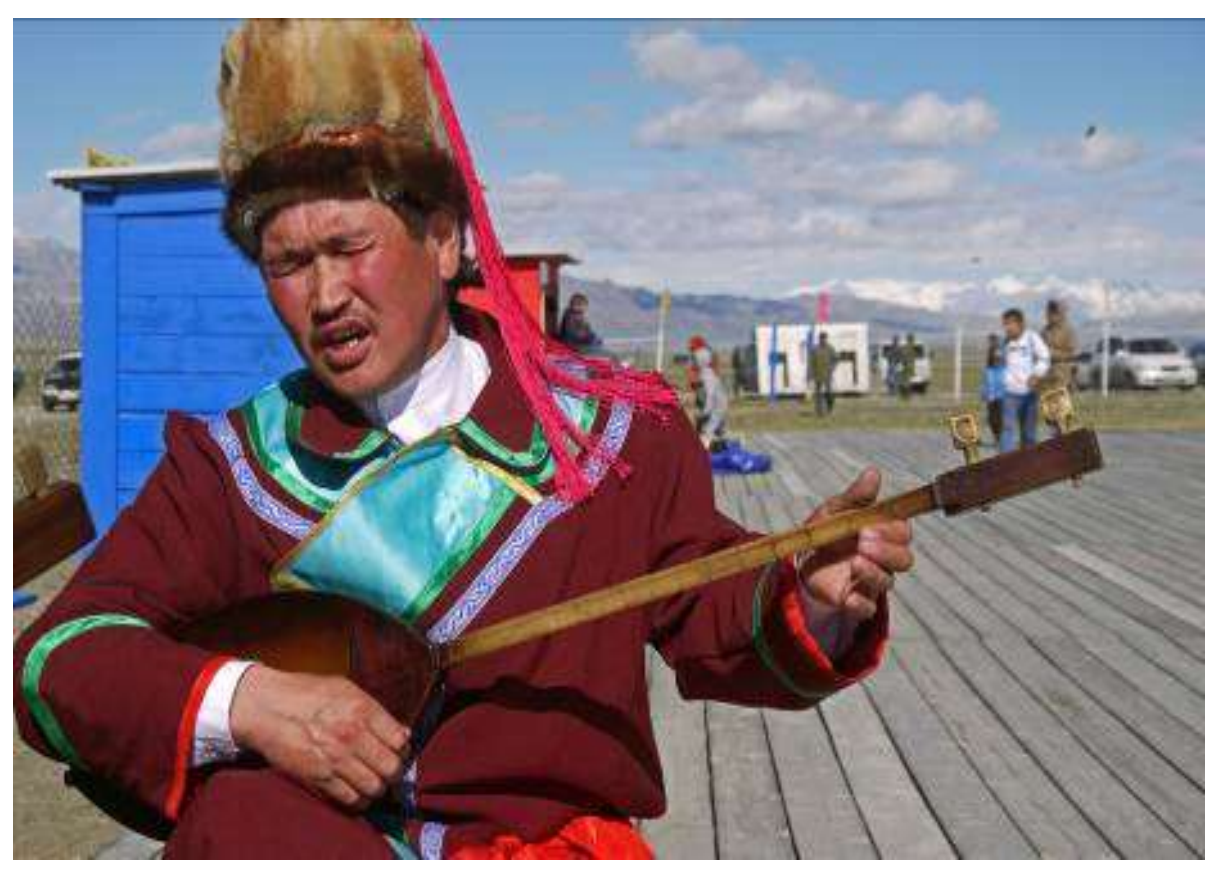




\subsection{Do fim da URSS à ressurreição da epopeia?}

Desde a década de 1980, o canto de garganta tem sido associado principalmente à onda de "conjuntos tradicionais", que apareceram em toda a Rússia nessa época ${ }^{37}$. Atualmente, mais e mais jovens altaianos estão se voltando para essa prática. Ela é ensinada em escolas de música da república, e até escolas especializadas foram criadas para transmiti-la ${ }^{38}$, possibilitando integrar a escola de música de Abakan, na vizinha República de Khakassie $^{39}$, ou o Conservatório de Novossibirsk. A formação eventualmente permite que a pessoa consiga se tornar um funcionário do Estado, trabalhando como professor de música em escolas ou em uma das muitas Casas de Cultura, ou como artista no Teatro Nacional. Também podemos citar a possibilidade de ela iniciar uma carreira internacional. Com efeito, o canto de garganta não deixou de encontrar um lugar no interesse contemporâneo da chamada música "do mundo" ou "étnica". Além do interesse de um público ocidental em busca de exotismo e "autenticidade", fascinado por essas vozes incomuns, existem inúmeros nomes internacionais que, em períodos de gravação, formaram dueto com artistas altaianos, uma prática que é parte de uma dimensão totalmente "glocal", "isto é, onde o local e o global se misturam, influenciam-se mutuamente e de maneira plural ${ }^{40}$.

Os ocidentais associam bastante esse tipo de música aos movimentos de desenvolvimento pessoal e da Nova Era, nos quais ele é frequentemente apresentado como uma das técnicas do xamanismo, com efeitos benéficos e até virtudes meditativas para quem o utiliza ${ }^{41}$. De modo que, para

\footnotetext{
${ }^{37}$ Em Altai podemos citar o conjunto inovador "Čuja", criado em 1968, e o conjunto "Altai", fundado em 1986 por Vladimir E. Končev, que mais tarde se tornou Ministro da Cultura. Os membros mais proeminentes de "Altai", Nogon Šumarov e Bolot Bajrišev, são hoje considerados internacionalmente como os "embaixadores" do kaj altaiano e se apresentam em todo o mundo com músicos de renome.

38 Podemos citar a Escola de Música e Artes, ou a Oficina altaiana para meninos de "Altai" (ru. Altajskaja studija mal'čikov "Altaj"), criado por V. E. Končev.

${ }^{39}$ Convém observar que estudar a prática do canto de garganta, em uma paisagem cultural em que ele foi usado de maneira diferente de como existe em seu contexto original, pode levar o estudioso a correr o risco de abandonar, como J. During salienta, um bom número de "aspectos extramusicais que constituem a própria essência de uma tradição", bem como fazer o pesquisador reduzir a música a formas e técnicas (DURING, Jean, Globalisations de l'ère préindustrielle et formatage de l'oreille du monde. L'écoute de l'ethnomusicologue [Globalizações da era pré-industrial e formatação do ouvido do mundo. Ouvindo o etnomusicólogo]. In: BOUËT, J. \& SALOMOS, M. (Ed.). Musique et globalisation : Musicologie Ethnomusicologie [Música e globalização: Musicologia Etnomusicologia]. Paris: L’Harmattan, 2011, p. 61).

${ }^{40}$ REGNAULT, Madina. Encenação de heranças musicais em La Réunion e Mayotte. In: DESROCHES, Monique. Musique touristique et patrimoine à la Martinique. In : DESROCHES, Monique, PICHETTE, Marie-Hélène, DAUPHINE, Claude, SMITH, Gordon E. (éd.), Territoires musicaux mis en scène. Montréal : Presses de l'Université de Montréal, 2011, p. 109, citando Schuerkens, Ulrike, "The Sociological and Anthropological Study of Globalization and Localization", Current Sociology, vol. 51, $\mathrm{n}^{\circ}$ 3-4, 2003, p. 209-222. Podemos mencionar novamente N. Šumarov e B. Bajrišev, que trabalharam com músicos da Suíça e do Japão, respectivamente, bem como o conjunto altaiano "AltajKAJ", fundado em 1997 por U. Yntaev, que gravou um disco com a Orquestra Filarmônica de Praga (2007), outra durante uma turnê pelos Estados Unidos (2006). Esses

Dois álbuns são percebidos localmente como um índice indiscutível de sucesso. Do lado dos vizinhos da República de Altai, o grupo Huun Huur Tu e o cantor Sainkho Namtchylak, de Touva, colaboram regularmente com grupos alemães ou americanos. ${ }^{41} \mathrm{~A}$ associação entre canto de garganta e xamanismo continua a ser determinada, caso a caso, para os povos dispersos do Tibete ao Ártico, via Ásia Central (ver, em relação a esse assunto, a tese de J. Curtet dedicada à origem do canto mongol höömij; Curtet, A transmissão..., op. cit.). Ao contrário de outras regiões onde é praticada (Mongólia, Touva), raramente ouvi falar das virtudes benéficas do canto de garganta em Altai, além da perspectiva da Nova Era. Contudo, pude ver o jovem kajčy A. Közörököv, infelizmente falecido muito cedo, usando sua música em rituais de cura (MT 2011; Konunov, Altajdyク Kajčylary
} 
jovens praticantes altaianos, novas perspectivas, muitas vezes vistas como vantajosas, estão agora associadas ao que uma vez caracterizou a prática da recitação épica: notoriedade, sucesso financeiro,


para ocorrer a cada verão nas bases turísticas, diante de um público estrangeiro neófito completamente surpreso. Por conseguinte, faz sentido que o etnólogo altaiano S. Tjuhteneva veja no turismo e no interesse ocidental pela chamada música "étnica" as principais razões que levaram ao renascimento local (e, portanto, à sobrevivência) da prática do canto de garganta ${ }^{43}$.

A título de comparação, M. Desroches indica que, na Martinica, os espetáculos turísticos participam da conservação, revitalização e integração da prática musical viva que, de outra forma, se tornaria uma espécie de "patrimônio fossilizado, pouco executado pelos atores da herança viva" ${ }^{44}$. Ela também postula que a música e os shows apresentados para turistas são um vetor importante na construção da identidade cultural ${ }^{45}$. A atração das novas gerações de altaianos pelo canto de garganta é efetivamente justificada por seu lado "étnico". Faz parte da dinâmica atual, presente em quase toda parte na Sibéria, mesmo no mundo, de renovado interesse pelas culturas nacionais, tendendo a destacar as práticas locais altamente simbólicas, os aspectos históricos e as "raízes", contrabalançando, desse modo, os efeitos da globalização. Consequentemente, apesar de suas transformações ao longo do tempo, a prática musical altaiana, e em particular a do canto de garganta $k a j$, tornou-se um marcador de identidade distintivo, ajudando a vincular todos os grupos étnicos de Altai a uma memória coletiva e a um espaço simbólico e mitológico comum.

O fenômeno da patrimonialização, no sentido de se apropriar de uma prática cultural e reivindicar a herança inerente a essa prática, é um exemplo claro da revitalização da prática de execução épica sob uma perspectiva "étnica". É confirmado na República de Altai pelo decreto do governo de 14 de maio de 2015, sobre a "Adoção de um registro nacional dos bens patrimoniais da cultura imaterial da República de Altai" no qual aparecem, além de certas práticas religiosas, o caráter

\footnotetext{
..., op. cit., p. 8). Hoje em dia, essa idéia é disseminada principalmente no caso da Rússia, pela mídia "mainstream", em programas ou documentários de "choque". Como exemplo, citaremos o vídeo "Altaj - Put' v Šambalu" (Altai, o caminho para Shambala: https://www.youtube.com/watch?v=CjPe5t7PB_U), no qual o jovem músico altaiano A. Čičakov apresenta-se na casa de uma avó russa doente das pernas, que, após ouvir o canto, sente imediatamente seus benefícios! Quanto às chamadas virtudes meditativas do canto, se elas não são novas em relação aos altaianos [Anohin já falou sobre elas no início do século 20 (citado por ŠUL'GIN, Boris Mihajlovič. Ob altajskom kae [Sobre o kaj altaiano]. In: Maadaj-Kara, Altajskij geroičeskij èpos. Moscou: Nauka, 1973, p. 459)], é provável que essa ideia, de que existam tais virtudes, tenha se espalhado por todo o mundo através do budismo e, mais particularmente, pelos discos das canções dos monges tibetanos do mosteiro de Gyütö (rGyud-stod). Já ouvi o público europeu de músicos altaianos, touvas e mongóis, dizer que foi "transportado" pela música ou que experimentou um "estado de transe" durante os shows. O vídeo acima mencionado também contribui, do lado russo, para a disseminação de tais ideias, mas também para que o povo de Altai, como um todo, seja visto como budista. ${ }^{42}$ As turnês estrangeiras, muitas vezes combinando oficinas de canto com concertos, são importantes fontes de renda.

${ }^{43}$ TJUHTENEVA, Svetlana Petrovna. Zemlja, Voda, Han-Altaj : Ètničeskaja kul'tura Altajcev v XX veke [Terra, água, Han-Altaï: a cultura étnica dos altaianos no século 20]. Elista: Izdatel'stvo Kalmyckogo Universiteta, 2009, p. 51-52.

${ }^{44}$ DESROCHES, Monique. Musique touristique et patrimoine à la Martinique. In : DESROCHES, Monique, PICHETTE, MarieHélène, DAUPHINE, Claude, SMITH, Gordon E. (Ed.). Territoires musicaux mis en scène. Montréal : Presses de l'Université de Montréal, 2011, p. 73.

45 DESROCHES. "Musique...", op.cit., p. 62 ; p. 73.
} 
de kajčy, sua arte, seus contos e seus instrumentos. O decreto deve ser visto como um primeiro passo para a inclusão do kaj altaiano na lista de patrimônio mundial imaterial da UNESCO ${ }^{46}$. Localmente, a patrimonialização também é realizada através de distinções criadas para recompensar a arte dos bardos. É o caso do Prêmio G. I. Tchoros-Gourkine, que, desde 1991, homenageia as personalidades de Altai que trabalham nos campos culturais, políticos e artísticos, e pelo qual alguns músicos-kajčy foram homenageados (Aržan Közörököv em 1999, Conjunto AltajKAJ em 2004, Raisa "Tandalaj" Modorova em 2010, Sarimaj Určimaev em 2013). Mais recentemente (2011), vimos o Prêmio A. G. Kalkin, em homenagem ao último grande bardo da região, dedicado especialmente às pessoas que trabalham para a conservação e disseminação de práticas artísticas na república (pesquisas também podem ser reconhecidas) $)^{47}$.

O evento principal desta patrimonialização da prática do canto de garganta e da recitação épica contemporânea permanece, todavia, o Encontro Internacional de Cantores Épicos (Kajčylardyn telekejlik Kurultajy), uma competição realizada anualmente e durante a qual os praticantes confrontam-se exibindo suas proezas, tanto vocais (técnicas de canto) quanto intelectuais (através do conhecimento de extratos épicos aprendidos de cor nos livros ou na criação de obras originais). A realização do evento, o crescente número de participantes de todo o mundo e, acima de tudo, a participação das mulheres testemunham a mania contemporânea da técnica vocal do kaj. Para dar mais força a essa tendência, a cada ano é destacada a idade do participante mais jovem ( 9 anos até o momento $\left.{ }^{48}\right)$.

Ao mesmo tempo, ao distinguir as diferentes técnicas de canto de garganta (ou canto difônico), a competição contribui para o alargamento da paleta vocal associada à recitação épica: de fato, vimos que o kaj só poderia ser gutural, e só recentemente a recitação épica conseguiu integrar outras técnicas vocais (sygyt, höömei, borbannadyr...), importadas das áreas vizinhas de Altai (Touva e Mongólia em particular) ${ }^{49}$. Essa circulação entre culturas vizinhas é um caso típico do que J.-L. Amselle caracteriza como "conexão"50, a qual atesta a intensidade das trocas e as múltiplas inspirações que

\footnotetext{
46 Postanovlenie Pravitel'stva Respubliki Altaj ot 14.05.2014 n'140 “Ob utverždenii gosudarstvennogo reestra ob"ektov nematerial'nogo kul'turnogo nasledija Respubliki Altaj" [Despacho do Governo da República de Altai n ${ }^{\circ} 140$ de 14/05/2014 "Sobre a ratificação da lista oficial de bens do patrimônio cultural imaterial da República de Altai]. No total, são listados 21 bens culturais, incluindo práticas religiosas e "personagens mitológicos" (como divindades veneradas) de diferentes sistemas de representação (xamanismo, burcanismo, tengriismo...). As discussões sobre a inscrição do kaj altaiano na lista do patrimônio mundial imaterial já começaram com representantes das regiões vizinhas de Altai, onde também é praticado o canto de garganta (site de informações http://www.gorno-altaisk.info/news/49917\#more-49917, de 26/02/2016, acessado em 28/02/2016).

47 Decreto ${ }^{\circ} 173-u$ do Presidente e do Chefe do Governo da República de Altai, de 28/06/2011.

${ }^{48} \mathrm{Com}$ relação à idade em que começar a recitar o épico, o pai do bardo quirguiz Jusup o alertou para não "contar as façanhas [de Manas] até que ele tenha mais de 40 anos. Um jovem não deve dizer o épico" (citado por Jacquesson "Os bardos ... ", op. cit., p. 23).

${ }^{49}$ Nos referimos ao vídeo mencionado na nota 5.

50 AMSELLE, Jean-Loup, Branchements. Anthropologie de l'universalité des cultures [Conexões. Antropologia da universalidade das culturas]. Paris: Flammarion, 2001.
} 
giram em torno do épico e que contribuem para sua renovação. Nesse sentido, podemos ver que a busca pela autenticidade não é mais feita apenas pelos turistas, senão que se tornou também uma questão importante para as populações locais, e está em processo permanente de construção.

\subsection{0 kajčy, protótipo do músico altaiano contemporâneo?}

Uma observação importante deve ser feita sobre os músicos-cantores "de garganta" contemporâneos. A partir do momento em que o músico faz uso desse tipo de música, ele se apresenta rapidamente como - ou é qualificado como - kajčy, independentemente da idade e de seu conhecimento de textos épicos. Cumpre observar que, em relação aos textos épicos, muitas vezes ouvimos atualmente em Altai que não há mais um kajčy capaz de recitar um poema épico inteiro ${ }^{51}$. E, como se fosse para confirmar esse boato, a maioria dos cantores de garganta que conhecemos memorizou apenas trechos épicos dos textos editados (porém, como veremos, um deles, Termil Terkišev, recentemente tentou fazer uma recitação na sua totalidade ${ }^{52}$ ).

Os extratos aprendidos pelos bardos são cantados em diferentes contextos, muitas vezes politizados, após o período soviético. Além das bases turísticas, podemos ouvir alguns versos retirados de um épico durante a competição de que falamos ou durante concertos comemorativos de uma data histórica, para a inauguração de um prédio público ou salão temático. Contudo, o canto de garganta também faz parte da vida cotidiana dos habitantes da república e pode ser ouvido em segundo plano em comerciais de TV ou em rádio para lojas locais ${ }^{53}$.

Na medida em que o contexto muda, o status do artista evolui, de maneira que podemos legitimamente fazer a pergunta sobre a caracterização deste último. De fato, os cantores contemporâneos de garganta, que não confinam sua prática musical apenas à recitação épica "tradicional", podem ser chamados de kajčy? Editando coleções de músicas, como os bardos tibetanos dos quais N. Gauthard ${ }^{54}$ fala, participando de documentários sobre suas práticas, atuando "dans une contemporanéité en lien avec les phénomènes de globalisation, notamment avec l'utilisation des

\footnotetext{
51 Também observado pelo folclorista altaiano A. Konunov (Altajdyn Kajčylary ..., op. cit, p. 9). Vários músicos contemporâneos se apresentam como kajčy nas coletâneas musicais que eles publicam por si mesmos. Convém acrescentar que, de acordo com os altaianos, alguns kajčy contemporâneos às vezes têm apenas um conhecimento superficial da língua altaiana!

52 A tentativa de E. Terkišev ocorreu à noite, em público, durante o festival de Èl-Ojyn no verão de 2014. Cabe observar, contudo, que, em 2003, os músicos do grupo AltajKAJ já se revezavam há mais de 4 horas para conquistar o recorde mundial na categoria maior execução em poesia épica em $k a j$ (http://www.vesti.ru/doc.html?

id=18429, acessado em 10/04/2017). Sabemos que foi o épico de Maadaj-Kara que foi recitado, porém não temos mais informações sobre como foi realizado. Provavelmente, foi apenas um trecho, tendo cada um dos músicos aprendido uma parte do texto completo. De fato, leva cerca de uma hora para recitar 1000 versos; sabendo que o épico conta 7738 versos, estimamos que sua recitação completa levaria de 6 a 8 horas.

53 Isso inclui anúncios de TV e rádio produzidos pela agência de comunicação local Planeta-Servis, ou a tela gigante localizada na Praça Lenin, em Gorno-Altaisk, que transmite anúncios utilizando o canto de garganta.

54 GAUTHARD, Nathalie. L’Épopée tibétaine de Gesar de Gling. Adaptation, patrimonialisation et mondialisation [A epopeia tibetana de Gesar de Gling. Adaptação, patrimonialização e globalização]. In : Cahiers d'ethnomusicologie, 24, 2011 , p. 186.
} 
nouvelles technologies de l'information et de la communication" [numa contemporaneidade ligada aos fenômenos da globalização, notadamente com o uso de novas tecnologias da informação e comunicação], desenvolvendo "dans une contemporanéité en lien avec les phénomènes de globalisation, notamment avec l'utilisation des nouvelles technologies de l'information et de la communication" [novos processos de transmissão e [demonstrando] que sabem usar as ferramentas da "modernidade" para apropriar-se de novos territórios de mídia além das fronteiras [de Altai]", os músicos altaianos são sempre kajčy $y^{55}$ ? Abertos à música pop ou ao rock, gêneros dos quais ele aceitam influência para suas composições, tentando sintetizar motivos tradicionais e sonoridades sintéticas ou envolvendo uma infinidade de instrumentos eletroacústicos, eles ainda podem levar o nome desses especialistas em rituais do passado? Não obstante, devemos ressaltar que essas experiências sonoras, do ponto de vista de seu público, são preferíveis à monotonia de uma recitação épica ${ }^{56}$. Admitamos desde já que a formação de conjuntos contemporâneos, como AltajKAJ, Novaja Azija ou Tala, inspirados nos hits internacionais do momento, dão um "soco" no canto de garganta e no topšuur, trazendo linhas de baixo e ritmos acelerados. De maneira que, a pergunta do intérprete, que merece ser feita, permanece pendente no momento.

\section{Uma recitação "à moda antiga". Quando o desenvolvimento do público transforma a epopeia}

Como mencionamos anteriormente, o kajčy È. Terkišev recentemente tentou recitar um épico na sua totalidade. Não poderíamos deixar de voltar a essa noite em particular, fruto do desejo de implementar um ideal de execução épica, motivo pelo qual nos permitimos falar de recitação "à moda antiga". Essa tentativa parece-nos uma boa ilustração do lugar do épico em Altai atualmente e é um excelente exemplo da influência que o público pode ter sobre o texto.

No festival Èl-Ojyn de 2014, o kaj esteve presente, como sempre, através do Encontro Internacional de Cantores (Kajčylardyn telekejlik Kurultajy), que mencionamos acima. A competição, como dissemos, é marcada por concursos oratórios envolvendo a técnica e o conhecimento de extratos de épicos, aprendidos em livros publicados. Parte da competição é dedicada à criação individual, entretanto os participantes permanecem poucos e geralmente fazem parte da geração de kajčy experientes, já reconhecidos. È Terkišev é um deles, ele decidiu marcar o ano com uma pedra branca, renovando o conceito de "vigília épica", recitando, durante duas horas, a epopeia Alyp-Manaš, que aprendeu em um livro ${ }^{57}$. De forma que, à meia-noite, no meio de julho, algumas pessoas se reuniram em um yurt (tenda ou cabana circular usada pelos pastores mongóis) para ouvir o bardo.

\footnotetext{
55 GAUTHARD, “L'épopée...”, op. cit.

${ }^{56}$ Confesso que não encontrei, durante minha pesquisa, pessoas ouvindo, apenas por prazer, recitações de poemas épicos em CD.

57 Duas horas de canto correspondem aproximadamente a 2000 versos.
} 
Confortavelmente instalado em uma pele de carneiro na parte de trás do yurt (o tör, local de honra), o qual fora montado numa elevação que destacava o bardo em relação ao seu público, È. Terkišev cantou com o alaúde topšuur, que ele acabara de ganhar no mesmo dia, na categoria "Mestre da arte do bardo" 58 .

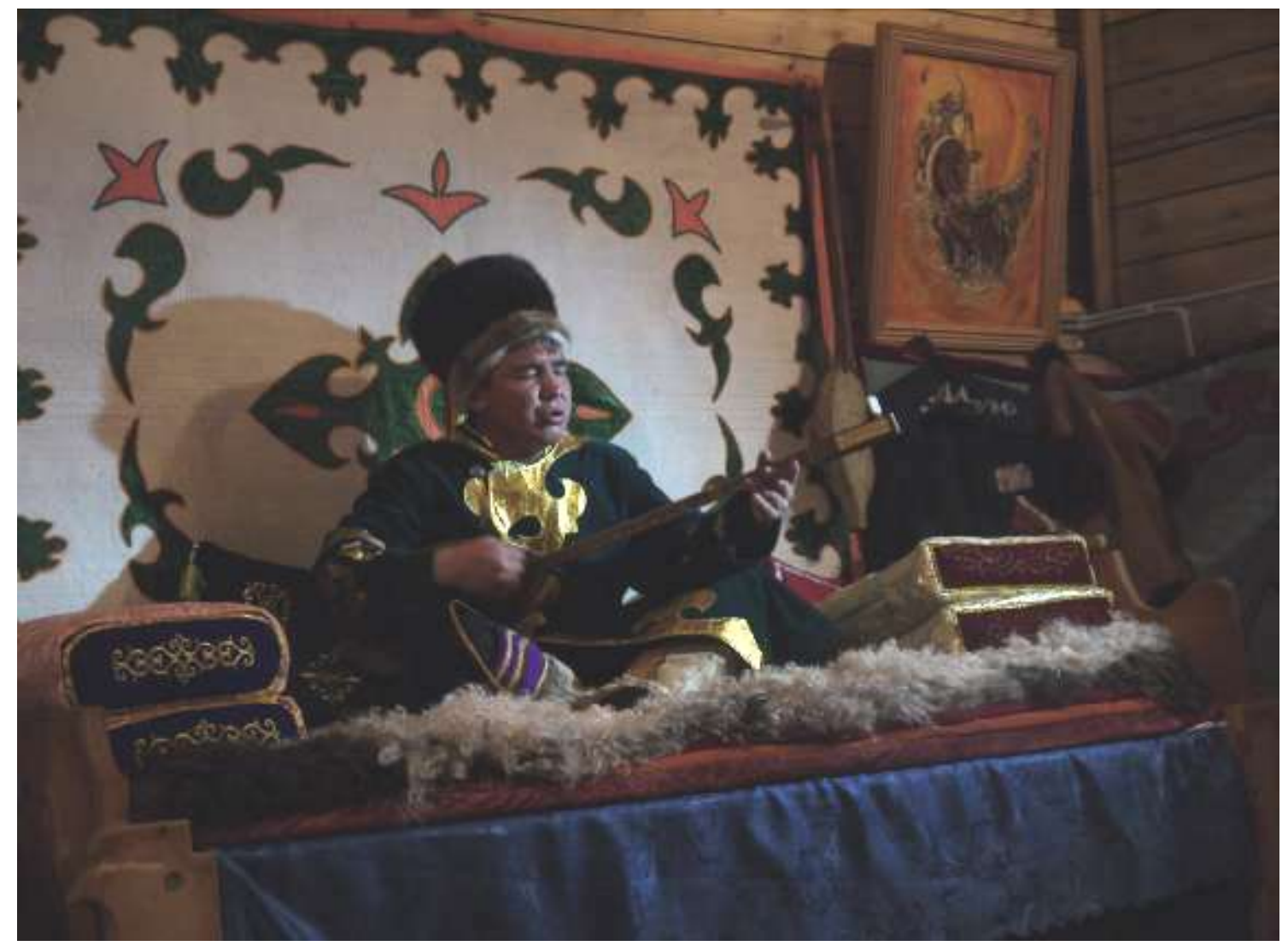

È Terkišev durante a recitação do épico de Alyp-Manaš (Elo, distrito de Ongudaj, junho de 2014). Podemos ver no final do braço do instrumento a placa que condecora o cantor com o título de "Mestre da arte do bardo".

Não havia nada de "tradicional" na plateia reunida: ao mesmo tempo, viam-se os nativos, que assistiam ao show pop dado no palco principal do festival, e a grande maioria da plateia, por sua vez composta de estrangeiros, turistas que passavam ou etnólogos e folcloristas, todos portando câmeras e gravadores. É a qualidade desse público, em grande parte neófito e especialmente pouco familiarizado com a língua altaiana - se não for completamente desconhecedor dela -, que torna a recitação não empolgante como era nos velhos tempos ${ }^{59}$, fazendo com que ela seja sentida, ao contrário, como tediosa e às vezes até sonolenta?

\footnotetext{
58 Os instrumentos conquistados durante a competição são sistematicamente fabricados por A. Ènčinov, artesão e músico em Koš-Agač.

59 KALAČEV (“Neskol'ko slov...”, op. cit., p. 490) para TELENGUITES, Dyrenkova (Šorskij Fol'klor, op. cit., p. XXXVII-XXXVIII) para CHORS, Jacquesson ("Les bardes... ", op. cit., p. 2) para os Quirguizes, cabe mencionar como os bardos são incentivados pelo público, quando eles cantam episódios particularmente emocionantes.
} 
O fato é que, ao tomar a iniciativa de recriar uma recitação épica à "moda antiga", em um contexto sociocultural e econômico completamente diferente, diante desse público absolutamente distinto do público das execuções do passado, È . Terkišev e os tomadores de decisão da noite "transformaram a tradição". Sabemos que o papel essencial da epopeia é disponibilizar ao público as várias possibilidades de saída da crise ${ }^{60}$. Nesse caso, estamos nos afastando dessa concepção do texto épico, já que não era ele o centro das atenções. Na verdade, inacessível ao público estrangeiro, aprendido de cor de uma fonte escrita - e, portanto, disponível para todos aqueles que sentissem a necessidade de ter um conhecimento detalhado dele, o épico de certa forma "desapareceu" do evento. O público neófito, que pôde assistir a recitações no início do dia, durante a competição épica de cantores, não possuía as chaves para avaliar o domínio da língua e a demonstração de um vocabulário rico, critérios fundamentais, para avaliar a arte do bardo no contexto tradicional, que determinavam a qualidade de sua recitação. Somente a duração e o contexto da performance, talvez o timbre da voz, permitiram ao público distinguir Terkišev de seus colegas ouvidos à tarde. Quanto à escassez do público nativo, essa levanta algumas questões: revela uma falta de interesse contemporâneo por parte dos altaianos pelo "material épico" ${ }^{61}$ ? Seria a resposta para o fato de uma recitação desse tipo ser considerada por eles como "não mais relevante", uma vez que lembra demais as recitações do passado sem ser uma delas, devido exatamente a tudo isso que as fazia tão distintas das recitações atuais (a época da execução , a "eficácia" esperada que difere ...)?

A ausência dos jovens cantores de garganta, os quais também já haviam participado da competição, pode ser considerada ainda mais surpreendente. Conquanto se interessem pela música tradicional, sabemos que a geração jovem, que se banha em um território cada vez mais inclinado à russificação (mídia, videogame, comércio... ${ }^{62}$ ), também é resistente a longos textos épicos. À medida que os jovens vão destacando o domínio do conhecimento "técnico" (canto de garganta, peça musical), o conhecimento ritual (textos) vai sendo deixado de lado em suas práticas ${ }^{63}$. Todavia, como M.-F. Mifune diz sobre o ritual bwiti entre os Fang, "les connaissances rituelles sont à la base de la pratique

\footnotetext{
60 GOYET, Florence et LAMBERT, Jean-Luc Lambert. Introduction. In : Études mongoles et sibériennes, centrasiatiques et tibétaines 45. Épopée et millénarisme: transformation et innovation, section 1: L’Épopée, un outil pour penser les transformations de la société. Sous la direction de F. Goyet et J. L. Lambert, 2014, en ligne : https://emscat.revues.org/2265, $\S 5$.

${ }^{61}$ Acrescentemos que as incessantes idas e vindas de boa parte do público do yurt testemunharam o sentimento de monotonia gerado pela recitação, sentimento que já mencionamos acima e que consideramos como a causa do pouco interesse atualmente dedicado ao épico.

62 Embora o altaiano seja o idioma oficial da república da mesma maneira que o russo, os documentos oficiais não são traduzidos para esse idioma. Apesar de falado em casa nas aldeias, não é usado para educação geral e é ensinado em toda parte como língua estrangeira. O único jornal nacional em altaiano, Altajdyn Čolmony (A Estrela de Altai), aparece uma vez por semana. Na televisão, o primeiro canal federal vai ao ar apenas alguns minutos por dia, para o tempo de que deveria dispor um boletim de notícias.

${ }^{63}$ Após minha participação em cursos e em entrevistas a jovens estudantes de escolas de música, posso, sem hesitar, afirmar que, se forem seduzidos pela prática musical e pela técnica do canto de garganta, provavelmente sua motivação não durará muito, sobretudo quando eles perceberem que terão, se escolherem esse caminho, que memorizar centenas de versos!
} 
rituelle et, réciproquement, la pratique rituelle est un support de mémorisation et d'actualisation de ces connaissances" ${ }^{\prime \prime 4}$ [o conhecimento ritual é a base da prática ritualística e, inversamente, a prática do ritual é um meio para memorizar e atualizar esses conhecimento]. Por consequência, testemunharíamos, de acordo com a fórmula de M. Mauss ${ }^{65}$, uma ruína desse "fato social total", que é uma recitação épica, devido à renovação fragmentada de apenas alguns aspectos, além disso amputados do elo responsável por ligá-lo à tradição. Assim, a performance de Terkišev, que pode ser entendida mais como uma resposta à busca de exotismo e autenticidade que emana de um público estrangeiro e neófito do que como uma solicitação indígena, questiona o conceito de patrimônio, ao mesmo tempo em que é um testemunho convincente da influência do público sobre a epopeia.

Devido à não compreensão do texto pelo público, questiona-se por que se tornou importante para o bardo realizar uma recitação na sua totalidade. Ele realizou um ritual? Ele esperava, segundo era comum acontecer no passado, alcançar outro público, como o mundo dos espíritos por exemplo? E, se sim, qual a eficácia esperada de um texto recitado em um contexto temporal, sociocultural e econômico totalmente diferente? Se houve um ritual, podemos vê-lo de várias maneiras: como uma espécie de "ritual de passagem" para o turista que, imerso em uma recitação "à moda antiga", terá experienciado a sensação de ter vivido um momento único - e poderá exclamar "eu estava lá!" -, porém também como um "rito de compartilhamento", conforme definido por M. Regnault, e no qual encontramos "une base d'accord commun implicite entre le [visiteur étranger], qui cherche à vivre une expérience nouvelle, et l'hôte local, qui accepte de partager sa culture" 66 (uma base de concordância implícita entre o [visitante estrangeiro], que procura viver uma nova experiência, e o anfitrião local, que aceita compartilhar sua cultura).

Nesse sentido, o bardo È. Terkišev também não estava em desvantagem: é inegável que esse desempenho Ihe permitiu mostrar singularidade entre seus pares. Seu status de grande bardo já estava bem estabelecido localmente; a noite acabou lhe servindo como uma oportunidade para ele renovar suas distinções e estabelecer esse status. Além disso, alcançando um público estrangeiro com uma verdadeira "proeza", ele se apresentou de uma maneira notável e, quem sabe, se havia um produtor escondido no meio do público, ele pode ter aberto as portas para uma carreira internacional ${ }^{67}$.

\footnotetext{
${ }^{64}$ MIFUNE, Marie-France. Rite et performance dans le culte du bwiti chez les Fang du Gabon [Rito e performance no culto do bwiti entre os Presas do Gabão]. In : DESROCHES, Monique, PICHETTE, Marie-Hélène, DAUPHINE, Claude, SMITH, Gordon E. (Ed.). Territoires musicaux mis en scène. Montréal : Presses de l'Université de Montréal, 2011, p. 307.

${ }^{65}$ MAUSS, Marcel. Essai sur le don. Formes et raisons de l'échange dans les sociétés primitives [Ensaio sobre o presente. Formas e razões para o intercâmbio nas sociedades primitivas]. In : L'Année Sociologique, 1923-1924, p. 30-186 [également : édition électronique réalisée par Jean-Marie Tremblay, professeur de sociologie au Cégep de Chicoutimi, en ligne: http://bibliotheque.uqac.uquebec.ca/index.htm.

66 REGNAULT. "Mise en scène ...", op. cit., p. 101.

67 Pelo menos, no nível da República de Altai, Terkišev não poderia ser mais reconhecido do que de fato já é. Também sabemos que o sistema de distinção funciona dentro de uma lógica de revezamento e que o bardo não pode ser coroado "Mestre da arte do bardo" pela segunda vez (materiais de campo 2011). Com relação à sua "proeza vocálica", não devemos
} 
Finalmente, pode-se perguntar se a ausência de um público nativo, a ignorância dos códigos de conduta por parte do público estrangeiro (que não se beneficiou de nenhuma introdução real sobre o que estava acontecendo) nem foi "guiado", quanto às regras de comportamento no yurt, nem também convidado a encorajar o bardo durante a recitação...), não resultariam em uma espécie de reunião perdida entre o bardo e seu público? Posto que se possa pensar que essa performance é estruturante socialmente, na verdade ela resulta em uma espécie de sentimento de negócios inacabados para a maioria dos atores, um sentimento paradoxal porquanto, durante muito tempo em Altai, uma epopeia não havia sido "concluída". As questões levantadas pela performance estudada refletem, pois, as transformações que afetaram a prática da execução épica que, enfatizamos mais uma vez, parecem-nos de fato resultar da influência do público sobre a obra recitada. Também é possível detectar essa influência nas breves recitações de trechos a que qualquer visitante de Altai pode assistir regularmente, e sobre as quais agora nos deteremos. Não obstante, essas novas produções, em vez de serem vistas como produções da epopeia propriamente dito, deveriam ser vistas mais como aquilo que F. Goyet vem chamando de "trabalho épico" e se enquadram no que pode ser caracterizado como "epopeia dispersa"68.

\section{Uma (nova) epopeia dispersa?}

A breve visão histórica e o exemplo acima nos permitiram compreender até que ponto, durante o século XX, a poesia épica passou do nível do ritual, ao qual estão associadas muitas regras e valores, à performance cênica, não menos imbuída de simbolismo, contudo desprovida de fundo xamânico. Vimos que as transformações que ocorreram, os novos contextos e as formas de executar o épico se devem tanto à influência dos movimentos locais pelo renascimento da cultura nacional, quanto à manifestação internacional de interesse pelas técnicas musicais singulares de recitação. Desse modo, esses fatores refletem a relação que os altaianos têm com seus textos épicos e sugerem que a técnica do canto de garganta e o domínio do alaúde topšuur têm precedência sobre os textos e seu conteúdo. Apesar disso, se desejamos aprofundar um pouco essa relação a partir de um ângulo contemporâneo, é essencial ampliar nosso corpus e insistir em certos textos em particular e em seus contextos de uso. Com efeito, certos textos recentes, cantados em kaj em ocasiões singulares, parecem-nos corresponder perfeitamente a um caso de "epopeia dispersa". A polifonia desenvolvida anteriormente na estrutura da narrativa épica, que forma a base da "obra épica" e "[permite] representar perante o ouvinte todas as soluções políticas possíveis, incluindo soluções completamente

esquecer que a técnica do canto de garganta mobiliza músculos da garganta que raramente são usados e que, portanto, em sua duração, tal canto prova ser muito difícil.

68 GOYET \& LAMBERT “Épopée et millénarisme ...”, op. cit. 
novas que nada mais na época tornava possível vislumbrar"69, desdobra-se através de uma multiplicidade de textos, cada um oferecendo uma saída para a atual crise política e socioeconômica, propondo o teste dessas soluções através do corpus épico completo. De fato, os diferentes tipos de música, executados na voz de garganta e acompanhados pelo alaúde topšuur por músicos que afirmam ser kajčy, formam simultaneamente um conjunto. Ouvidos pelo público em vários contextos, eles testemunham, em nossa opinião, a presença desse trabalho épico, no sentido de que sua combinação dá origem à polifonia, condição essencial, de acordo com F. Goyet, para o surgimento de uma nova epopeia ${ }^{70}$.

O corpus que estudamos abrange uma ampla variedade de textos que, embora não possam ser sistematicamente caracterizados como "epopeias", ainda assim mantêm um "tema heroico". De modo que falaremos de uma epopeia considerando-os juntos, como um todo. Cada um deles vem de um contexto religioso diferente e as expectativas sobre eles estão ligadas ao seu uso. Vimos que o retorno da religiosidade no final da era soviética foi caracterizado em Altai por uma oferta abundante de correntes (religiosas) diferentes. Atualmente, essa situação tem gerado fortes tensões ideológicas entre esses movimentos, abalando a república: enquanto o budismo está fazendo um avanço na cidade, junto à intelligentsia nativa, os habitantes das aldeias do centro, sem se sentirem preocupados, recorrem a práticas neoburcanistas ${ }^{71}$ ou se convertem a diferentes correntes originárias do protestantismo evangélico. Ainda existem alguns altaianos que dizem ser xamanistas. Poucos nativos adotam a ortodoxia, especialmente percebida como a religião "russa". Os textos nos quais trabalhamos vêm de músicos mais ou menos envolvidos nesses diferentes movimentos: um é evangélico, outro monge budista, um terceiro neoburcanista, e o último não professa uma obediência religiosa específica, embora mantenha uma visão xamânica do mundo.

Uma análise detalhada dessas formas inovadoras e intrigantes mostra que, como os textos que as precederam, elas são capazes de ajudar a pensar sobre a situação de crise atrás mencionada e atualmente vivida pelo povo altaiano. Esses textos e os contextos em que estão inseridos são, do nosso ponto de vista, ferramentas que nos a judam a pensar, porquanto todos manifestam expectativas políticas ligadas ao movimento religioso do qual emanam e respondem, cada um a seu modo, ao relacionamento que o público contemporâneo de Altai tem com a tradição de recitar. O todo que eles

\footnotetext{
${ }^{69}$ GOYET \& LAMBERT. “Introduction...”, op. cit., § 5.

70 GOYET . "De l'épopée ...", op. cit.; Goyet, Florence, "L'épopée refondatrice : extension et déplacement du concept d'épopée", Le Recueil Ouvert, 2016, en ligne: http://ouvroir-litt-arts.univ-grenoble-alpes.fr:8080/revues/projetepopee//revues/projet-epopee/165-le-travail-epique-definition-de-l-epopee-refondatrice, consulté le 2/05/2017. Selon l'auteure, l'épopée moderne “peut se déployer dans tous les genres, à condition qu'elle soit populaire, politique et polyphonique" [Segundo a autora, o épico moderno "pode ser utilizado em todos os gêneros, desde que seja popular, político e polifônico] (Goyet, "L'épopée ...", op. cit., résumé).

710 "neoburcanismo" tenta atualizar as práticas rituais burcanistas do início do século XX. O movimento apareceu já há alguns anos na República de Altai, e desenvolve-se principalmente sob a bandeira do grupo ativista religioso Ak-T'an ("caminho branco"), ele mantém uma atividade política muito forte, especialmente contra o budismo e o cristianismo, religiões percebidas por seus membros como importadas e impostas pelos tomadores de decisão política.
} 
formam constrói a visão da sociedade, confronta a agitação sociopolítica e oferece os meios para responder a esses problemas, revelando ao público uma gama de possibilidades diversas. De alguma forma, esse todo preenche as condições de possibilidade de um épico moderno.

\subsection{Uma epopeia cristã}

O primeiro texto estudado é particularmente significativo: intitulado Èšua, narra principalmente a história de Jesus ${ }^{72}$. Foi composto por um músico convertido ao pentecostalismo. A história, portanto, toma forma em um contexto de intensa cristianização, que é o da conversão. 0 autor segue o kajčy do passado, pois afirma ter recebido este texto em um sonho. Contudo, ele não teria sido inspirado pelos espíritos, senão diretamente pelo Espírito Santo, o que é compreensível, tratando-se de um pentecostal ${ }^{73}$. Há também uma introdução tradicional, caracterizada pela destreza no uso do alaúde topšuur. O subtítulo do texto é kaj-soot'y "conto [recitado em] canto de garganta"74, o que implica que estamos lidando aqui com uma "epopeia cristã".

Os temas desenvolvidos na narrativa são de fato fortemente cristãos. Os principais eventos do Antigo e do Novo Testamentos estão condensados lá. Observamos, todavia, que esses temas permanecem próximos aos encontrados em muitos das epopeias altaianas observadas durante o século XX: um "paraíso" é ameaçado por um inimigo que sacode a harmonia original e causa sua ruptura. $\mathrm{O}$ casal inicial, forçado a deixar seu país, deve dar à luz o libertador, e as expectativas são proclamadas: então um herói predestinado aparecerá. Enquanto os heróis altaianos geralmente nascem de forma milagrosa, de um casal já idoso, sem filhos, e na ausência de seu pai que está caçando há meses, Ėšua aqui, por sua vez, também nasce de modo milagroso de uma mãe virgem. Além disso, sua infância é extraordinária: ao passo que nos outros textos o herói cresce muito rapidamente e possui uma força sobre-humana, no nosso caso, Èšua deslumbra os antigos com sua grande sabedoria. Cercado por seus 12 alyp ("heróis, cavaleiros"), o herói confronta-se então com seu inimigo, o qual, entretanto, consegue conquistar um bom número de apoiadores de sua causa. Ėšua vai à luta, porém logo perde sua vida também ${ }^{75}$, o que, como os heróis épicos altaianos, permite que ele ressuscite. Enfim, a história termina com o retorno do herói ao território em que nasceu, esse "paraíso perdido" que, no nosso caso, será o Paraíso celeste. 0 texto termina com uma expectativa messiânica de seu retorno, como podemos encontrar em alguns épicos relacionados ao burcanismo ${ }^{76}$.

\footnotetext{
72 Èšua significa Jesus em hebraico.

73 Entrevista realizada em maio de 2011.

${ }^{74}$ O termo soot'y é sinônimo do termo čörčök "conto" (BASKAKOV \& TOŠČAKOVA, Ojrotsko ..., op. cit., p. 130). Segundo um informante (06/2017), também denota a transmissão de um ensinamento, de uma moral, como uma fábula.

75 Seu inimigo é chamado Èrlik, nome dado em homenagem à divindade que rege o mundo inferior (inferno), no sistema de representações altaianas, e que às vezes é apresentado como responsável pela morte das pessoas. Nesse caso, mesmo que não haja menção explícita a uma crucificação, Ėšua morre em Tuu baš, a "montanha da cabeça", ou seja, o Gólgota.

76 É o caso de várias versões do épico de Altaj-Buučaj (Jacquemoud, "Altaj-Buučaj, ...", op. cit.).
} 
Essa narrativa contemporânea pode ser comparada com a epopeia de Altaj-Buučaj, na qual o herói se torna Messias e libertador de um povo oprimido. Como Altaj-Buučaj (e os outros heróis épicos altaianos), Èšua é chamado de baatyr ("cavaleiro"), o que o coloca no mesmo nível desses personagens. R. Hamayon, referindo-se a A. Dundes" ${ }^{77}$, nos diz que "le merveilleux de la naissance est l'un des traits qui autorisent à reconnaître dans la vie de Jésus la présence d'un modèle héroïque classique" $^{78}$ [o nascimento maravilhoso é um dos traços que nos permitem reconhecer na vida de Jesus a presença de um modelo heróico clássico].

Pode-se perguntar por que alguns episódios muito importantes na vida de Jesus não aparecem. Pode-se, por exemplo, citar a traição de Judas. Nesse caso, sabendo que a traição e o envenenamento do herói são assuntos pouco frequentes nas epopeias altaianas ${ }^{79}$, essa ausência é facilmente explicada. Todas essas características permitem afirmar que estamos na presença de um texto imbuído de um tom épico profundamente marcado, oferecendo também uma forma de compromisso entre o tema épico clássico e a mensagem cristã. Ambos se encontram misturados e podem ser percebidos pelo ouvinte.

Além disso, se considerarmos que o contexto, no qual esse texto costuma ser usado, é muito específico, toda a dimensão política dessa "epopeia" contemporânea se revela. De fato, apesar de considerado um artista talentoso, o músico, por ser membro de um movimento religioso considerado uma "seita" na Rússia, não costuma ser convidado a intervir e cantar em manifestações oficiais. Não obstante, ele é convidado pelas várias paróquias da vasta comunidade evangélica da Rússia e, às vezes, viaja de um extremo ao outro da Federação para recitar sua "epopeia" nas igrejas. De maneira que o texto profundamente religioso é assimilado a um ritual de louvor ao "Altíssimo". E pode também ser visto como uma forma renovada dos épicos do passado, destinado a atrair as boas graças dos espíritos da floresta durante a caça.

Existe uma versão em DVD do canto. Gravuras de Albrecht Dürer inseridas no filme acompanham esse relato da vida de Jesus. Porém, também podemos ver o músico realizando sua recitação na frente de um cume nevado, à margem de um córrego da montanha ou até ajoelhado diante de uma grande chama, decorações que são todas imagens do Altai (ver a sobrecapa). A inserção de quadros referentes ao sistema tradicional de representação altaiano adiciona peso simbólico

\footnotetext{
77 DUNDES, Alan. The Hero Pattern and the Life of Jesus. In: Essays in Folkloristics. Delhi : Folklore Institute, 1978, p. 223270.

${ }^{78}$ HAMAYON, Roberte. La "tradition épique" bouriate change tout en étant facteur de changement. In : Études mongoles et sibériennes, centrasiatiques et tibétaines 45, Épopée et millénarisme : transformation et innovation, section $1:$ L'Épopée, un outil pour penser les transformations de la société, sous la direction de F. Goyet et J. L. Lambert, 2014, en ligne : http://emscat.revues.org/2277. Acessado em 30 de junho de 2014, § 41.

79 JACQUEMOUD, "Altaj-Buučaj, ...", op. cit. Pode-se dizer que, em certo sentido, a história é atualizada em Altai, visto que também não há menção a romanos e a judeus. Por outro lado, o tema do dilúvio é brevemente abordado, bem como o é tanto o profeta João, que batiza o herói Ėšua, quanto a peregrinação deste no deserto, como as tentações do diabo por ele sofridas, assim como também suas habilidades enquanto agente de milagres, seus ensinamentos e sua ressurreição.
} 
significativo ao texto: ele não é mais apenas cristão, antes reivindica ser também tipicamente altaiano, o que também reforça sua inserção no contexto tradicional de recitação de poemas épicos. Para concluir este ponto, acrescentemos que a compra de uma cópia do disco também não é um ato sem sentido: pelo contrário, apóia a posição dos convertidos, em relação à situação política e religiosa contemporânea de Altai e à sua ação reivindicativa. Em outras palavras, adquirir o DVD e ouvir a música equivalem a expressar expectativas para um futuro melhor, como podem ter sido as canções de louvor burcanistas do início do século XX, semelhantes às epopeias.

Finalmente, o canto de garganta é novamente destacado aqui, e seu uso nos permite ver, no contexto religioso do cristianismo, um ritual comparável ao dos poemas épicos do passado. Obviamente, espera-se uma eficácia simbólica desse ato, que se une ao das orações e louvores do cristianismo. Além disso, como um presente de Deus, não pode haver uso recreativo do texto. Por conseguinte, entendemos esse texto - que articula posições antagônicas - e seu contexto de uso como exemplos concretos e sólidos, demonstrando a continuidade e a renovação da tradição de recitação épica e como testemunho da influência do público sobre o conteúdo do texto. Ao apresentar o cristianismo evangélico como um dos caminhos possíveis para sair da crise, percebemos esse texto como uma voz dentro de um todo polifônico, o que corresponde bem ao que F. Goyet definiu como "trabalho épico" em uma epopeia moderna "dispersa".

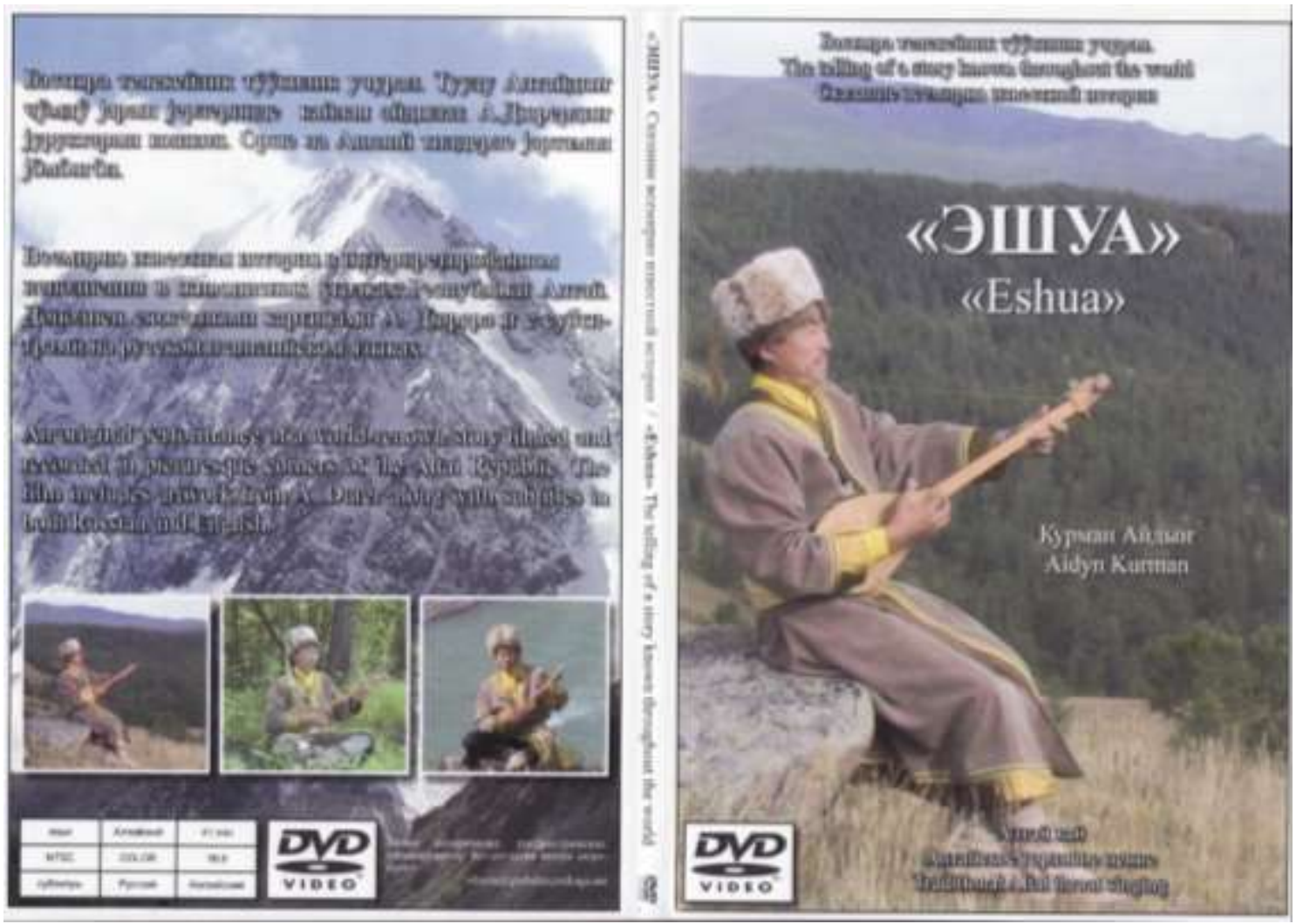

Capa do DVD Èšua por A. Kurman e fotografias do autor ilustrando seu texto datilografado. Notemos a abundância de símbolos referentes ao sistema de representação popular (o sol, a lua, o rio, as montanhas, a pele de ovelha na qual o bardo recita ...) 


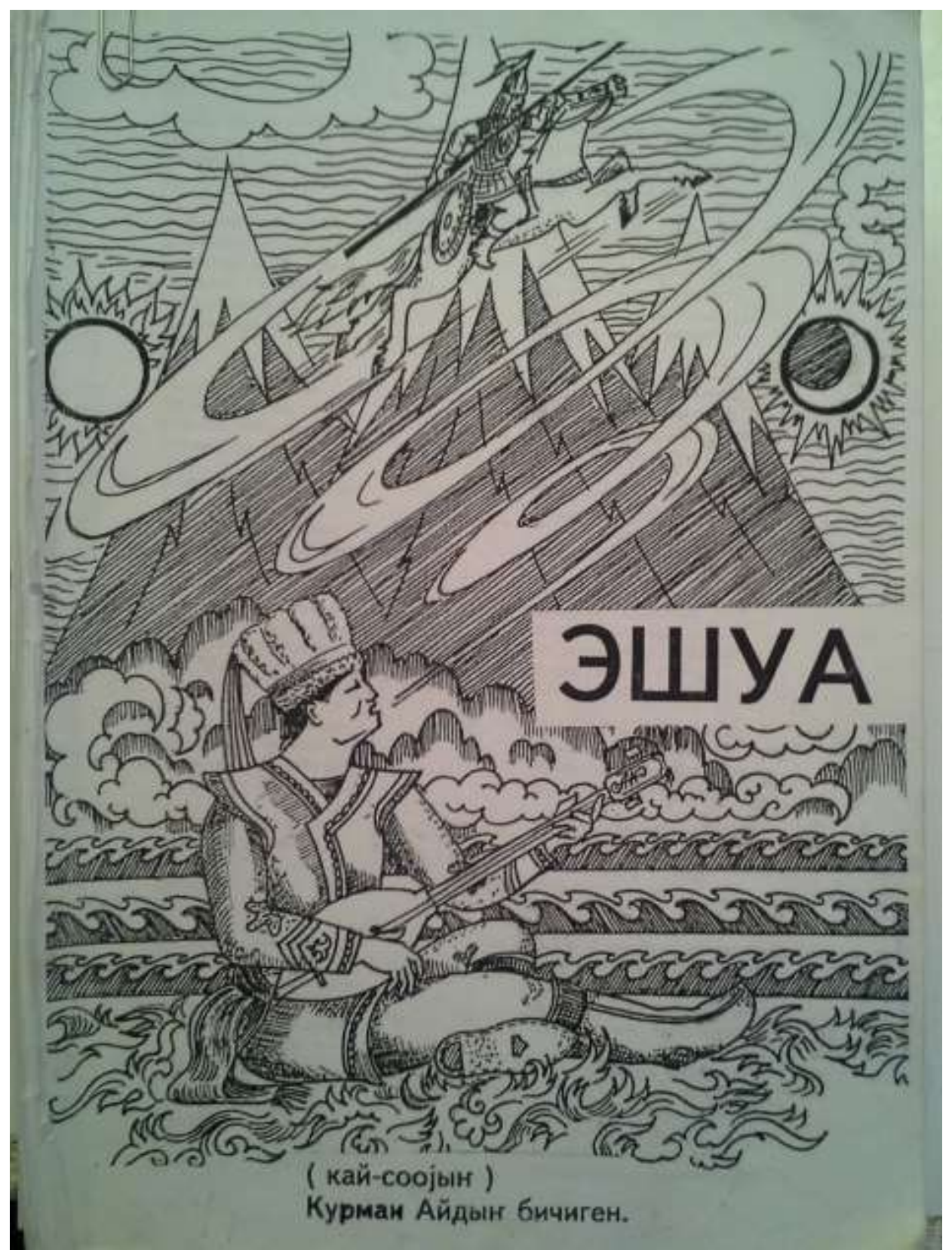

\subsection{Uma canção de louvor a Ak-Bourkhan}

O segundo texto contemporâneo que pudemos estudar é uma canção de louvor dedicada à divindade Ak-Bourkhan, uma figura associada ao movimento religioso burcanista. Originalmente composto por E. M. Čapyev (1910-2001), o texto é definido como música e cantado como canto de garganta por S. Určimaev, um monge budista que também se apresenta como kajčy.

Interessante por diversas razões, o texto pode antes de tudo ser comparado aos textos épicos por sua forma, e encontramos nos caracteres mencionados (Ak-Bourkhan, Altaj-èèzi, Üč-Kurbustan e 
Kajrakan) certas características dos heróis dos épicos: eles têm roupas com botões (topčylu) e cinto (kur), elementos essenciais na visão de mundo altaiana, associados respectivamente a uma vida longa e uma barriga cheia ${ }^{80}$. A divindade Ak-Bourkhan desce do céu em um arco-íris (a cavalo?), tem um coração (t'ürektü), um umbigo (kindiktü) e sobrancelhas (kirbiktü) ${ }^{81}$. Finalmente, o livro de sutras mencionado (altyn sudur bičiktü "com um livro de sutras de ouro") está presente em muitos épicos do início do século $X X^{82}$. Tudo isso, bem como o canto de garganta e o alaúde topšuur, para a execução performática, nos ajudam a inscrever esse texto na continuidade da tradição de recitação de poemas épicos.

Contudo, ao retomar esse texto, o músico budista contemporâneo substitui a divindade suprema do burcanismo, inserindo o poema em um contexto budista ${ }^{83}$. Entre os testemunhos convincentes, lembraremos o mantra Om mani padme hum pronunciado no final do canto e a menção do livro de sutras. É claro que se pode perguntar se essas referências são de autoria do autor ou do cantor $^{84} .0$ fato é que, no atual contexto religioso apresentado acima, a associação desse texto ao budismo pode assumir uma coloração política. De fato, na imaginação dos altaianos, Ak-Bourkhan e as outras divindades mencionadas provêm do burcanismo, um movimento religioso libertador, anticolonial e fortemente anti-russo. Substituir essas entidades em um canto (de um campo?) budista só pode provar ser uma tentativa de fortalecer o estabelecimento local do movimento religioso, à medida que contribui para a disseminação de suas ideias. Por fim, percebemos que o budismo também é apoiado pela intelligentsia atual no poder.

Estamos, portanto, testemunhando uma completa inversão de perspectiva. Os melhores tempos esperados do burcanismo estão agora associados à veneração de um Ak-Bourkhan budista. Mais peso é acrescentado a essa recuperação quando Ak-Bourkhan é aproximado da figura do mestre do povo de Altai, o espírito Altaj-èèzi, entidade que traz felicidade e atualmente é venerada pela maioria dos altaianos ${ }^{85}$. Enfim, o canto está disponível para venda em CD e, como no DVD de Ėšua, há

\footnotetext{
80 JACQUEMOUD, Clément. Les Altaïens, peuple turc des montagnes de Sibérie [Os altaianos, povo turco das montanhas da Sibéria]. Genebra-Paris: Fundação Cultural - Museu Barbier-Mueller, Somogy, 2015, p. 120.

81 Os heróis geralmente não têm um umbigo, o que ajuda a associá-los a seres extraordinários e a atribuir uma origem divina a eles. Em contraste, Ak-Bourkhan "com umbigo e coração" tende a se aproximar mais da humanidade.

$82 \mathrm{Em}$ Altai, no passado, pessoas alfabetizadas (que haviam estudado em mosteiros mongóis) eram chamadas sudurčy, ou seja, pessoas capazes de ler sudur, sutras budistas (KOS'MIN, Vitalij Konstantinnovič. Mongolian Buddhism's Influence on the Formation and Development of Burkhanism in Altai. In: Anthropology \& Archeology of Eurasia, 45(3), 2006-7, p. 59). Vemos nesse livro um testemunho da influência do burcanismo. Frequentemente, o filho do herói pede à nova esposa de seu pai que lhe diga onde está sua noiva predestinada, uma resposta que ela encontra consultando um livro de sutras sudur bičik. ${ }^{83}$ Deve-se notar também que a organização budista local, à qual o músico é afiliado, também leva o nome de Ak-Bourkhan. ${ }^{84} \mathrm{~A}$ origem do texto pode realmente ser questionada. Até onde consegui saber, parece que seu autor, um conhecido letrista do período soviético que escreveu muitas canções para a glória do Partido, oferece paradoxalmente um texto com uma forte conotação religiosa. Čapyev poderia muito bem ter participado dos últimos rituais burcanistas da década de 1920, ter ocultado secretamente o texto da oração até o relaxamento religioso da década de 1980 e, depois, tê-lo publicado. Ele também poderia apenas tê-lo escrito. Dentro desse contexto, a pergunta sobre se o mantra foi ou não originalmente observado por Čapyev, é, portanto, totalmente pertinente.

${ }^{85}$ Altaj-èèzi é venerado não apenas pelos burcanistas, mas também pelos xamanistas e às vezes ainda pelos convertidos à ortodoxia (ou seja: à Igreja Ortodoxa Russa).
} 
problemas semelhantes aqui em relação à sua compra. Pois que uma solução política é apresentada com esse texto, sem dúvida menos radical ou mesmo oposto ao preconizado um século antes pelos burcanistas, essa solução consiste em sugerir o ingresso em um movimento religioso mundial, ao mesmo tempo reconciliando-se com o poder local e até mesmo beneficiando-se de seu apoio.

Uma observação final pode ser feita sobre o canto de garganta usado. Como vimos acima, hoje em dia essa técnica está fortemente associada ao budismo, os famosos monges tibetanos do mosteiro Gyütö a usam para recitar seus mantras. O canto de garganta, portanto, contribui para a inscrição desse texto, ao mesmo tempo na continuidade de uma tradição local, quanto por dar mais força à recuperação da divindade e sua inserção nessa religião mundial. De modo que este texto altaiano encontra idealmente seu lugar em um continuum religioso budista muito amplo e torna possível fazer dessa religião uma segunda voz (caminho!) para sair da crise.

\subsection{Učar-kaj, entidade inspiradora dos bardos neoburcanistas}

O terceiro caso que apresentamos vem do movimento religioso Ak-T’an (que caracterizamos como "neoburcanismo"). Os cantos desse movimento são recitadas no contexto do ritual sazonal por um especialista que também se define como kajčy. A atmosfera é muito solene e, sem dúvida, é possível esperar eficácia do rito de execução. O louvor é dirigido a Altai, na forma da entidade espiritual Khan-Altaj ${ }^{86}$. A peculiaridade desses textos, novamente recitados no canto de garganta, é que eles são totalmente improvisados. De fato, o cantor diz que está em contato com a entidade espiritual Učarkaj (a "canção de garganta voadora" ${ }^{87}$ ), que fala através dele durante o ritual. Aqui encontramos uma das principais ideias dos épicos do passado, a saber, a de que os bardos que cantam a canção o fazem por inspiração dos espíritos. Convém observar que essa capacidade do bardo também faz parte de seu movimento religioso. Com efeito, o neoburcanismo é, entre seus membros, caracterizado pela presença recorrente do dom da escrita automática (channeling/canalização). Esse testemunho de vínculos diretos entre os seguidores do movimento contemporâneo e entidades espirituais, incluindo Khan-Altaj, contribui para manifestar uma continuidade em relação ao movimento burcanista tal como ele era em suas origens.

Essa continuidade também é encontrada no tom reivindicador de outros textos neoburcanistas. Em verdade, textos "inspirados" mostram uma virulência surpreendente contra a atual situação sociopolítica, apresentando Altai como a pátria dos altaianos, que foi arrancada deles e

\footnotetext{
${ }^{86}$ Também chamado de Bij-Altaj ("Rico Altai"). Khan-Altaj pode ser considerado como o nome "original" do espírito de Altai, usado no burcanismo no início do século XX. Atualmente é bastante obsoleto, abandonado em favor de sua designação Altajèèzi (Tjuhteneva, Zemlja, Voda ..., op. cit.).

87 Deve-se notar que a etimologia do termo kaj também se refere à idéia de "voar para longe, deslizar, ferver" (BASKAKOV \& TOŠČAKOVA. Ojrotsko ..., op. cit., p. 67).
} 
anexada pela Rússia, e que se encontra hoje em dia, por um propósito político, artificialmente mantida em estado de pobreza.

Por conseguinte, mesmo que não estejamos aqui na presença de textos claramente de tonalidade épica, a entidade Khan-Altaj anteriormente cantada pelos bardos burcanistas aparece, todavia, como uma entidade libertadora. Nesse sentido, os textos, colocando-se na continuidade do movimento burcanista tal como esse se apresentava nas origens, mergulham os participantes do ritual em seu contexto de surgimento, ou seja, em um contexto marcado por uma situação de profunda crise de identidade.

\subsection{Cantar uma canção "épica"?}

Outros textos contemporâneos desenvolvidos por músicos posando como kajčy também chamaram nossa atenção. Essas são as canções Kaj čörčöktin tynyžy ("A alma das epopeias"), Altaj kaj ("A canção de garganta de Altai") e Baatyrdyy sözi ("As palavras do cavaleiro") de Èmil' Terkišev8, e Sanbaškaj ("Epopeia estranha") de Karyš Kergilov ${ }^{89}$. Esses textos, muito curtos, são executados no canto de garganta seguindo a continuidade da tradição de recitação épica, contudo fazem isso trilhando caminhos distintos. Enquanto Terkišev canta as recitações do passado à beira do fogo, narra o aparecimento de cavaleiros em Altai e os perigos que aguardam a geração jovem (esquecimento das tradições, alcoolismo ...), Kergilov se demorará nos excessos do mundo contemporâneo e, forçando a nota, fará de seus anfitriões, mesmo os mais grosseiros, os novos heróis do nosso tempo. Esses músicos, assumindo uma forma estilística e uma maneira de execução da epopeia, a partir de textos significativos, colocam em palavras "questionnements identitaires, tels que le ressentiment par rapport au passé colonial et le contexte socioéconomique" (REGNAULT, 2011, p. 109) [questões de identidade, como o ressentimento em relação ao passado colonial e ao contexto socioeconômico]. Eles tornam a música um espaço de crítica social.

Por sua abordagem única do gênero, esses textos, combinados com os apresentados acima, formam um todo, sugerindo uma situação de crise, e cada um oferece, à sua maneira, uma solução política para sair dela, fazendo com que o público tenha que levar em consideração essa diversidade no momento de apreciar cada texto. Este conjunto não apenas renova a epopeia, senão também constitui sua polifonia.

\footnotetext{
88 TERKIŠEV, Èmil'. T'üregimde - Kaj, T’anarym - Altaj [No meu coração - o kaj, Mon t'anar - l'Altai]. Gorno-Altaïsk: Edição do autor, 2009, p. 12-14, 20 e 72. O t'anar é um tipo de canto tradicional de Altai.

89 KERGILOV, Karyš. Kuulgazyn èles [Um momento mágico], Gorno-Altaïsk, Edição do autor, 2007, p. 36-42. Podemos deduzir que, ao brincar com as palavras sanbaška "estranho" e kaj "canto de garganta", o autor esteja querendo transmitir a ideia de uma espécie de épico contemporâneo.
} 


\section{Conclusão}

Como parte de nossa análise, focando a poesia épica altaiana em sua dimensão contemporânea, vimos primeiro como ela era realizada no passado. Essa abordagem nos permitiu determinar que o canto de garganta, no qual a execução é considerada um elemento de alta relevância, bem como o acompanhamento do alaúde topšuur eram suas principais características. 0 modo vocal específico e o instrumento acabaram por ser os fios de nossa análise, que se estenderam ao longo dos séculos XX-XXI. De fato, durante todo esse período (marcado em particular pelo controle do regime soviético sobre as culturas nacionais), a prática da recitação épica passou por muitas transformações: os instrumentos evoluíram, foram inseridos em orquestras nacionais, os bardos se tornaram profissionais e sua música em particular, enquanto se expandia em novos tons, foi gradualmente relegada a um tipo de sobrevivência folclórica. Essas transformações deram origem, do nosso ponto de vista, ao que J. During chamou de "mouvement de déterritorialisation des motifs régionaux reterritorialisés au plan de l'art" ${ }^{90}$ [movimento de desterritorialização de motivos regionais reterritorializados em termos de arte]. Ao mesmo tempo, os textos também foram diluídos para entrar no quadro do pensamento político do regime.

Desde a queda da URSS, as culturas nacionais conheceram uma tremenda abertura para o mundo, e a prática do canto de garganta se globalizou, tornando-se, para muitos povos da região de Altai, um emblema cultural. Desejando saber se essa ênfase no canto foi praticada em detrimento do conteúdo dos textos, examinamos as diferentes condições sob as quais ele foi usado na República de Altai. Observamos então que as epopeias não são mais recitadas, exceto em fragmentos, enquanto o timbre singular de vozes é rasgado, numa dinâmica de patrimonialização ${ }^{91}$, entre características identitárias e argumento turístico. Além disso, a ampliação dos contextos em que o canto de garganta está agora inscrito é caracterizada por um cenário eminentemente político, "bardos" contemporâneos usando essa técnica vocal para manifestar seu posicionamento religioso ou realizar críticas sociais, por meio de textos inspirados no épico, mas repensados. Tudo isso atesta uma "renovação do épico" que, por um lado, atende às expectativas do público a que esses textos se destinam e, por outro lado, abraça em sua dinâmica de difusão as novas mídias e tecnologias de informação e comunicação.

De forma que, sem querer generalizar a epopeia em toda a produção oral contemporânea de Altai, deve-se reconhecer que o gênero inspira essas novas formas, algumas das quais permanecem altamente rituais. Elas estão ligadas à epopeia por sua técnica de execução, pelos temas heroicos que destacam e, sobretudo, pelas palavras que realçam uma situação de crise. Mesmo que o público local

\footnotetext{
90 DURING, “Globalisations ...", op. cit., p. 45.

91 No sentido de se apropriar de uma prática cultural e reivindicar a herança inerente a essa prática (GAUTHARD

“L”Epopée...", op. cit., p. 173).
} 
nem sempre fale de "epopeias" para caracterizá-los, a maioria dos textos despertará nele, para citar F. Goyet, "un éblouissement en tant que récit de hauts faits caractérisé par un grandissement et un souffle "épiques", et [va apparaître] comme une mise en ordre du réel (style formulaire, scènes-type, fin déjà connue)" 92 [um deslumbramento semelhante ao que ocorre em um conto de fatos caracterizados por um crescimento e uma respiração "épicos" e [aparecerá] como uma ordenação da realidade (estilo de forma, tipo de cena, final já conhecido)". É através dessa pluralidade de novas formas, pois, que vemos o "trabalho épico", "dynamique qui, dans un certain nombre de grandes épopées, permet de faire émerger la nouveauté politique" ${ }^{93}$ [dinâmico que, em um certo número de grandes epopeias possibilita que surjam novidades políticas. Além disso, nos perguntamos se a "polifonia" interna do texto épico, definida por F. Goyet como "capacité du récit à faire coexister des voix contradictoires sans en récuser aucune" ${ }^{\prime 94}$ [capacidade da narrativa de fazer coexistirem vozes contraditórias sem se questionar nenhuma delas], não é finalmente encontrada atualmente "extirpada" na multiplicidade de performances inspiradas no épico.

Com efeito, numa forma épica "dispersa", esses textos seriam as novas ferramentas intelectuais que propõem as diferentes opções políticas oferecidas a todos para superar a atual crise de identidade em Altai. A "articulação de posições antagônicas, embora todas sustentáveis em uma dada situação histórica" ${ }^{\prime 95}$, parece, portanto, estar distribuída entre todas as produções dos cantores contemporâneos de "garganta" de Altai e contribui para o fato de a jovem geração estar interessada em sua rica herança oral. Enquanto os textos longos narrando as extraordinárias aventuras de um herói perdem a aura e tendem a desaparecer no mundo digital, o gênero renasce em textos curtos, porém capazes de desempenhar o papel do épico antigo, fazendo com que o ouvinte vislumbre as diferenças políticas possíveis.

\section{Referências bibliográficas}

Archives A. G. Danilin de l'Institut d'ethnographie N. N. Mikluho-Maklaj de l'Académie des Sciences de Russie.

AMSELLE, Jean-Loup. Branchements. Anthropologie de l'universalité des cultures. Paris : Flammarion, 2001.

AUBERT, Laurent. Comment exposer la musique et que lui faire dire. In: DESROCHES, Monique, PICHETTE, Marie-Hélène, DAUPHINE, Claude, SMITH, Gordon E. (Ed.). Territoires musicaux mis en scène, Montréal, Presses de l'Université de Montréal, 2011, p. 13-40.

\footnotetext{
92 PROVINI, Sandra. Resumo da intervenção de Florence Goyet: Penser sans concepts : fonction de l'épopée guerrière [Pensar sem conceitos: a função da epopeia guerreira. In: Camenae, 4, 2008, online: http://www.paris-sorbonne.fr/IMG/pdf/CRFGoyet_epopee-guerriere.pdf, acessado em 15/04/2017.

93 GOYET, “Do épico...", op. cit., § 1.

94 GOYET, "Do épico...", op. cit., § 12.

95 PROVINI, "Resumo...", op. cit.
} 
BASKAKOV, Nikolaj Aleksandrovič \& TOSCAKOVA, Taisija Makarovna. Ojrotsko-russkij slovar' [Dictionnaire Oïrote-russe], Moscou, OGIZ, Gosudarstvenoe Izdatel'stvo Inostrannyh i Nacional'nyh Slovarej, [1947] 2005.

BAZIN, Louis. Les systèmes chronologiques dans le monde turc ancien. Budapest : Akadémiai Kiadó, Paris, CNRS éditions, 1991.

BUTANAEV, Viktor Jakovlevič. Tradicionnyj šamanism Xongoraja [O xamanismo tradicional de Khongoraï]. Abakan: Izd-vo Hakasskogo Gosudartsvennogo Universiteta im NF Katanova, 2006.

BUTANAEV, Viktor Jakovlevič \& BUTANAEVA, Irina Isaevna. Hakasskij istoričeskij fol'klor [Le folklore historique khakasse]. Abakan, 2001.

CURTET, Johanni. La transmission du höömij, un art du timbre vocal : ethnomusicologie et histoire du chant diphonique mongol. Tese de doutorado, sob a supervisão de Alain Desjacques. Rennes: Universidade Rennes 2, 2013.

DANILIN, Andrej Grigor' evič. Burhanizm, Iz istorii nacional'no-osvoboditelnogo dviženija contra Gornom Altae [Burcanismo. História de um movimento nacional libertador na Altai montanhosa]. Gorno-Altaïsk: Ak Čeček, 1993.

DEMČINOVA, Mira Alčinovna. Vvedenie, Skazitel' Nikolaj Ulagašev : Altajskie geroičeskie skazanija [O bardo Nicolas Ulagašev : contos heroicos altaianos]. Gorno-Altaïsk: Ministerstvo Kul'tury Respubliki Altaj, Gosudarstvennoe naučnoe učreždenie Respubliki Altaj “Naučno-Issledovatel'skij Institut Altaistiki im. S. S. Surazakova", 2011.

DESROCHES, Monique. Musique touristique et patrimoine à la Martinique. In : DESROCHES, Monique, PICHETTE, Marie-Hélène, DAUPHINE, Claude, SMITH, Gordon E. (éd.), Territoires musicaux mis en scène. Montréal : Presses de l'Université de Montréal, 2011, p. 61-74.

DUNDES, Alan. The Hero Pattern and the Life of Jesus" [A figura do herpoi e a vida de Jesus]. In : Essays in Folkloristics. Delhi : Folklore Institute, 1978, p. 223-270.

DURING, Jean. Globalisations de l'ère préindustrielle et formatage de l'oreille du monde. L'écoute de l'ethnomusicologue [Globalizações da era pré-industrial e formatação do ouvido do mundo. Ouvindo o etnomusicólogo]. In: BOUËT, J. \& SALOMOS, M. (Ed.). Musique et globalisation : Musicologie Ethnomusicologie [Música e globalização: Musicologia Etnomusicologia]. Paris: L'Harmattan, 2011, p. 39-68.

DYRENKOVA, Nadežda Petrovna. Šorskij Fol'klor [Coro folclórico]. Moscou: Léningrad, Izdatel'stvo Akademii Nauk SSSR, 1940.

FUNK, Dmitri Anatol'evič. Miry šamanov i skazitelej. Kompleksnoe issledovanie teleutskih i šorskih materialov [Os mundos dos xamãs e dos bardos. Estudo complexo de materiais dos teleoutes e dos chors]. Moscou: Nauka, 2005.

GAUTHARD, Nathalie, “L'Épopée tibétaine de Gesar de Gling. Adaptation, patrimonialisation et mondialisation [A epopeia tibetana de Gesar de Gling. Adaptação, patrimonialização e globalização]. In: Cahiers d'ethnomusicologie, 24, 2011, p. 173-189.

GOYET, Florence. L'épopée. In: Vox Poetica, 2009, online: http://www.voxpoetica.org/sflgc/biblio/goyet.html, acesso em 10/10/2013.

GOYET, Florence. De l'épopée canonique à l'épopée "dispersée" : à partir de l'lliade ou des Hōgen et Heiji monogatari, quelques pistes de réflexion pour les textes épiques notés. In : Études mongoles et sibériennes, centrasiatiques et tibétaines 45, Épopée et millénarisme : transformation et innovation, section 1 : L'Épopée, un outil pour penser les transformations de la société, sous la direction de F. Goyet et J. L. Lambert, 2014, en ligne : http://emscat.revues.org/2366 
GOYET, Florence e LAMBERT, Jean-Luc. Introduction. In: Études mongoles et sibériennes, centrasiatiques et tibétaines 45. Épopée et millénarisme : transformation et innovation, section 1 : L'Épopée, un outil pour penser les transformations de la société, sob a direção de F. Goyet e J. L. Lambert, 2014. Disponível em: https://emscat.revues.org/2265), consulta em 30 de setembro de 2016.

GOYET, Florence. L'épopée refondatrice : extension et déplacement du concept d'épopée. In : Le Recueil Ouvert, 2016, en ligne : http://ouvroir-litt-arts.univ-grenoble-alpes.fr:8080/revues/projetepopee//revues/projet-epopee/165-le-travail-epique-definition-de-l-epopee-refondatrice.

GOYET, Florence. Penser sans concepts : fonction de l'épopée guerrière [Pensar sem conceitos: a função da epopeia guerreira]. In: Camenae, 4, 2008, online: http://www.parissorbonne.fr/IMG/pdf/CR-FGoyet_epopee-guerriere.pdf, acessado em 15/04/2017.

HAMAYON, Roberte. The Dynamics of the Epic Genre in Buryat Culture - a Grave for Shamanism, a Ground for Messianism. In: JANSEN, Jan \& MAIER, Henk M. J. (Ed). Epic Adventures - Heroic Narrative in the Oral Performance Traditions of Four Continents. Münster: LIT Verlag, 2004, p. 53-66.

HAMAYON, Roberte. La chasse à l'âme - Esquisse d'une théorie du chamanisme sibérien [A Caçada à alma - Esboço de uma teoria de xamanismo siberiano]. Nanterre: Société d'ethnologie, 1990.

HAMAYON, Roberte. La "tradition épique" bouriate change tout en étant facteur de changement. In : Études mongoles et sibériennes, centrasiatiques et tibétaines 45, Épopée et millénarisme : transformation et innovation, section 1 : L'Épopée, un outil pour penser les transformations de la société, sous la direction de F. Goyet et J. L. Lambert, 2014, en ligne : http://emscat.revues.org/2277.

HARVILAHTI, Lauri. Altai Oral Epic. In: Oral Tradition, 15, 2, 2000, p. 215-229.

HARVILAHTI, Lauri. The Holy Mountain. Studies on Upper Altay Oral Poetry. Helsinque: Suomalainen Tiedeakatemia Academia Scientiarum Fennica, 2003.

HOHOLKOV, Vladimir Fedorovič. Muzykal'nye instrumenty Gornogo Altaja [Os instrumentos da música do Altai montanhoso]. Gorno-Altaïsk: autoédition, 2004.

IVANOVNA, Tatiana Grigorievna. La littérature orale narrative et son utilisation dans la période stalinienne. In : Ethnologie française, XXVI, 4, 1996, p. 727-737.

JACQUEMOUD, Clément. Barde et chamane, Étude anthropologique comparative de deux spécialistes rituels en République d'Altaï (Sibérie méridionale) [Bardo e xamã, Estudo antropológico comparativo de dois especialistas em rituais na República de Altai (sul da Sibéria)]. Mémoire de Master II [Tese de mestrado II]. Paris: École Pratique des Hautes Études, 2009.

JACQUEMOUD, Clément. Altaj-Buučaj, herói épico entre os dois séculos. In : Études mongoles et sibériennes, centrasiatiques et tibétaines 45 , Épopée et millénarisme : transformation et innovation, section 1 : L'Épopée, un outil pour penser les transformations de la société, sous la direction de F. Goyet et J. L. Lambert, 2014, en ligne : http://emscat.revues.org/2292.

JACQUEMOUD, Clément. Les Altaïens, peuple turc des montagnes de Sibérie [Os altaianos, povo turco das montanhas da Sibéria]. Genebra-Paris: Fundação Cultural - Museu Barbier-Mueller, Somogy, 2015.

JACQUESSON, Svetlana. Les bardes kirghiz : initiations, apprentissages, pratiques [Bardos quirguizes: iniciações, aprendizagens, práticas]. Comunicação durante o seminário de Revel, Nicole e ServanSchreiber, Catherine. Les épopées : littératures de la voix. Apprentissages et fonctions [As epopeias: literaturas da voz. Aprendizagens e funções]. Paris: Centro de Pesquisa em Oralidade, 1999.

KALAČEV, A. Neskol'ko slov o poèzii telengitov [Algumas palavras sobre a poesia dos Télenguites]. In: Živaja Starina, 3-4, 1896, p. 489-500.

KERGILOV, Karyš. Kuulgazyn èles [Um momento mágico], Gorno-Altaïsk, Edição do autor, 2007. 
KONUNOV, Arkadij. Altajdyn Kajčylary - Kajčy Altaja [Os kajčy de Altai]. Gorno-Altaïsk: Ministerstvo Kul'tury Respubliki Altaj, Respublikanskij Centr Narodnogo Tvorčestva, Nauatno-Issued Altaistiki im SS Surazakova, 2010.

KOPTELOV, Afanasij Lazarevič. Kajčy N. U. Ulagašev. [O kajčy N. U. Ulagašev]. In: Sibirskie ogni, 1, 1941. KOS'MIN, Vitalij Konstantinnovič. Mongolian Buddhism's Influence on the Formation and Development of Burkhanism in Altai. In: Anthropology \& Archeology of Eurasia, 45(3), 2006-7, p. 43-72.

LEBENDINKSIJ, Lev Nikolaevič. Isskustvo uzljau u baškir [A arte dos uzlau chez les Bachkires]. In: Sovetskaja Muzyka, 4, 1948.

MAJNOGAŠEVA, Valentina Evgen'evna. Hakasskij geroičeskij èpos "Altyn-Aryg"[L'épopée héroïque khakasse "Altyn-Aryg"]. In: Altyn-Aryg, Hakasskij geroičeskij èpos. Moscou: Nauka, 1988, p. 490-534.

MARSH, Peter K. The Horse-head Fiddle and the Cosmopolitan Reimagination of Tradition in Mongolia. Nova York, Londres: Routledge, 2009.

MAUSS, Marcel. Essai sur le don. Formes et raisons de l'échange dans les sociétés primitives [Ensaio sobre o presente. Formas e razões para o intercâmbio nas sociedades primitivas]. In: L'Année Sociologique, 1923-1924, p. 30-186 [également: édition électronique réalisée par Jean-Marie Tremblay, professeur de sociologie au Cégep de Chicoutimi, en ligne: http://bibliotheque.uqac.uquebec.ca/index.htm.

MIFUNE, Marie-France. Rite et performance dans le culte du bwiti chez les Fang du Gabon [Rito e performance no culto do bwiti entre os Presas do Gabão]. In : DESROCHES, Monique, PICHETTE, MarieHélène, DAUPHINE, Claude, SMITH, Gordon E. (Ed.). Territoires musicaux mis en scène. Montréal : Presses de l'Université de Montréal, 2011, p. 295-310.

PEGG, Carole. Ritual, Religion and Magic in West Mongolian (Oirad) Heroic Epic Performance. In: British Journal of Ethnomusicology, Vol. 4, 1995, p. 77-90.

PEGG, Carole. Mongolian Conceptualisations of Overtone Singing (xoomii). In: British Journal of Ethnomusicology, Vol. 1, 1992, p. 31-54.

PROVINI, Sandra. Résumé de l'intervention de Florence Goyet: Penser sans concepts : fonction de l'épopée guerrière. In : Camenae, 4, 2008, en ligne : http://www.paris-sorbonne.fr/IMG/pdf/CRFGoyet_epopee-guerriere.pdf.

PUHOV, Innokentij Vassil'evič, "Altajskij narodnyj geroičeskij èpos" [O épico popular heroico altaiano]. In: Maadaj-Kara, Altajskij geroičeskij èpos. Moscou: Nauka, 1973.

RADLOFF, Friedrich Wilhelm. Proben der Volkslitteratur Dernördlischen Stämme: Theil V [Amostras de literatura popular das tribos do norte]. São Petersburgo, 1885.

REGNAULT, Madina. Mise en scène des patrimoines musicaux à La Réunion et à Mayotte. In: DESROCHES, Monique. Musique touristique et patrimoine à la Martinique. In : DESROCHES, Monique, PICHETTE, Marie-Hélène, DAUPHINE, Claude, SMITH, Gordon E. (éd.), Territoires musicaux mis en scène. Montréal : Presses de l'Université de Montréal, 2011, p. 93-112.

REICHL, Karl. O épico oral turco da Ásia Central. In: Études mongoles et sibériennes, 32, 2001, p. 7162.

REYNOLDS, Dwight F. Heroic Poets, Poetic Heroes: The Ethnography of Performance in an Arabic Oral Epic Tradition. Ithaca: Cornell University Press, 1995.

SCHUERKENS, Ulrike. The Sociological and Anthropological Study of Globalization and Localization. In: Current Sociology, Vol. 51, nº 3-4, 2003, p. 209-222.

STOJANOV, Anatolij Konstantinovič. Isskustvo hakasskih hajdži [A arte dos hajdži khakasses]. In: AltynAryg, Hakasskij geroičeskij čpos. Moscou: Nauka, 1988, p. 577-590. 
SURAZAKOV, Sazon Sajmonovič. Biografija skazitelja A.G. Kalkina [Biografia do bardo A. G. Kalkin]. In: Maadaj-Kara, Altajskij geroičeskij èpos. Moscou: Nauka, 1973, p. 439-442.

EJKIN, Jurij Il'ič e NIKIFOROVA, Vera Semenovna. Altajskoe èpičeskoe intonirovanie" [A entonação épica altaiana]. In: Altajskie geroičeskie skazanija. Novosibirsk: Nauka, 1997, p. 47-70.

ŠERSTOVA, Ljudmila Ivanovna, Burhanizm: istoki ètnosa i religii [Burcanismo: as fontes étnicas e religiosas]. Tomsk: Tomskij gosudarstvennyj universitet, 2010.

ŠINŽıN, Ivan (Tanispaj) Boksurovič. Skazitel’ A. G. Kalkin [O bardo A. G. Kalkin]. Gorno-Altaïsk: GornoAltajskij Naučno-Issledovatel'skij Institut Istorii, Jazyka i Literatury, 1987.

ŠUL'GIN, Boris Mihajlovič. Ob altajskom kae [Sobre o kaj altaiano]. In: Maadaj-Kara, Altajskij geroičeskij èpos. Moscou: Nauka, 1973, p. 454-459.

TERKIŠEV, Èmil'. T'üregimde - Kaj, T'anarym - Altaj [No meu coração - o kaj, Mon t'anar - l'Altai]. Gorno-Altaïsk: Edição do autor, 2009.

TJUHTENEVA, Svetlana Petrovna. Zemlja, Voda, Han-Altaj : Ètničeskaja kul'tura Altajcev v XX veke [Terra, água, Han-Altaï: a cultura étnica dos altaianos no século 20]. Elista: Izdatel'stvo Kalmyckogo Universiteta, 2009.

ZNAMENSKI, Andrei. Power of Myth: Popular Ethnonationalism and Nationality Building in Mountain Altai. 1904-1922. In: Acta Slavica laponica, 22, 2005, p. 25-52.

\section{Referências on-line}

http://www.gorno-altaisk.info

http://www.vesti.ru/doc.html?id=18429

Video da canção "Kajčylar" [Le dialogue des bardes] de l'ensemble AltajKAJ, extraída do álbum XXI century (2006) : https://www.youtube.com/watch?v=s1FVDOfGNBA

Video Altaj - Put' v Šambalu [Altaï, le chemin pour le Shambhala], on-line: https://www.youtube.com/watch?v=CjPe5t7PB_U. 